\section{Marija Perkec}

samostalna istraživačica independent researcher

J. J. Strossmayera 63, Virovitica, Hrvatska

marija.perkec@gmail.com

(iD)

orcid.org/0000-0002-5280-0048

Pregledni rad

Subject review

UDK / UDC:

77 Vesović, $\mathrm{M}$.

DOI:

10.17685/Peristil.60.12

Primljeno / Received:

30. 6. 2017.

Prihvaćeno / Accepted: 10. 10. 2017.

\section{Novinska fotografija Mije Vesovića (1976.-1990.)}

\author{
Newspaper Photography by Mio Vesović \\ (1976-1990)
}

\section{APSTRAKT}

U članku se na osnovi istraživanja fotografija objavljenih u časopisima Polet, Studentski list, Start i Danas analizira angažman Mije Vesovića na području novinske fotografije. Fotografije nastale u razdoblju od 1976. do 1990. godine razmatraju se u kontekstu tematskih, tehničko-stilskih, socioloških i kulturoloških odrednica kako bi se obuhvatili svi aspekti Vesovićeve fotografske produkcije toga razdoblja.

\section{KLJUČNE RIJEČI}

Mio Vesović, „nova novinska fotografija“, „Nova life-fotografija“, Polet, Studentski list, „Meko okidanje“

\begin{abstract}
The paper discusses the work of Mio Vesović as newspaper photographer for magazines Polet, Studentski list, Start and Danas. The author analyses his photographic contributions between 1976 and 1990 in the context of thematic, technological, stylistic, sociological and cultural conditions in order to cover all aspects of Vesović's work of the period.
\end{abstract}

\section{KEYWORDS}

Mio Vesović, "new newspaper photography“, „new life-photography“, Polet, Studentski list, , Soft shooting" 


\section{Uvod}

Krajem 1970-ih i početkom 1980-ih u hrvatskoj se umjetnosti javljaju termini „nova novinska fotografija“, „Poletova škola fotografije“ i ,Nova life-fotografija “ kako bi se opisao novi pristup novinskoj fotografiji iniciran u redakciji omladinskog časopisa Polet (1976.-1990.). ${ }^{1}$ Zahvaljujući oživljavanju interesa za reportažnu i socijalnu fotografiju afirmirana je čitava generacija mladih fotografa, a među njima i Milisav Mio Vesović (Gornja Dobrinja, 1953.). ${ }^{2}$ Iako su Vesovićeve fotografije neizostavan segment kada je riječ o novom pristupu novinskoj fotografiji, njegov angažman u tiskovinama, izvan okvira izložbenog sustava, nije cjelovito istražen. ${ }^{3}$ Članak se temelji na istraživanju fotografija objavljenih u časopisima Polet, Studentski list (1946.1998.), Danas (1982.-1992.) i Start (1962.-1991.) u cilju valoriziranja i objavljivanja fotografija koje nisu uvrštene u funduse izložbenih institucija. ${ }^{4}$ Istraživanje je vremenski određeno 1976. godinom kada Vesović započinje s radom u Studentskom listu te 1990. godinom kada politički, ekonomski i tržišni uvjeti mijenjaju pristup novinskoj fotografiji. ${ }^{5}$ Kako bi se obuhvatili svi aspekti Vesovićeve fotografske produkcije $u$ istraživanje su, uz medijsku klasifikaciju (tematsku i tehničko-stilsku), uključeni povijesni, socijalni i kulturni narativ. ${ }^{6}$

\section{Kulturni kontekst kasnih 1970-ih}

Unatoč teškoj ekonomskoj i političkoj situaciji u Jugoslaviji, posljednje je desetljeće postojanja države na kulturnom polju obilježeno inovativnim modelima umjetničkog izražavanja. ${ }^{7}$ Takvu je opoziciju političko-ekonomskog i kulturnog polja kasnih 1970-ih uvjetovao senzibilitet u okviru kojeg pojedinci do tada marginaliziranim i nepoželjnim oblicima izražavanja stvaraju drugačiji stav prema stvarnosti, samostalan i individualan, u odnosu na kolektivni stav zadan u identitetnim formulama službene kulture. ${ }^{8}$ Prihvaćanjem zapadnih glazbenih obrazaca - britanskog i američkog punka i new wavea, te stvaranjem specifičnoga lokalnog izraza tih pojava, u tekstovima se pjesama punka i njegove komercijalizirane varijante novog vala na prostoru Jugoslavije počinju javljati teme koje upućuju na generacijske probleme mladih i tematiziraju njihovu sredinu - grad i zagrebački Duhanski put. Prisutne su bile i teme regionalizma te ostalih pripadnika društvene strukture koji su se susretali s razmjerom društvenih normi i svakodnevne prakse. ${ }^{9}$ Uz glazbu, i u drugim medijima (omladinski tisak, fotografija, strip, fanzini, dizajn omota ploča, grafiti i radio) primjetan je senzibilitet tzv. novog realizma čime se punk $\mathrm{i}$ novi val potvrđuju kao oblik kulturnog jezika. ${ }^{10}$ Posredstvom tih medija kulturni diskurs postaje individualnim komentarom svakodnevnog života, postojećega kolektivnog sustava vrijednosti, stvara pravo na subjektivnost $\mathrm{i}$ individualnost $\mathrm{u}$ cilju samospoznaje i stvaranja novog identiteta gdje se strip javlja kao komentar, grafiti i fanzini kao statement, a fotografija „kao medij kojim se bilježi život jedne sredine i generacije ". ${ }^{11}$ Upravo je zato razdoblje kasnih 1970-ih i ranih 1980-ih vrijeme afirmiranja čitave plejade mladih autora: glazbenika i sastava (Azra, vis Idoli, Pankrti, itd.), autora stripova okupljenih u grupi „Novi kvadrat“ (R. Devlić, K. Skorzet, J. Marušić, M. Ilić, K. Zimonić, I. Kordej), novinara (N. Pavić, D. Kuljiš, Z. Franičević) i fotografa okupljenih oko omladinskog časopisa Polet (M. Vesović, D. Dučak, S. Knaflec, I. Posavec, D. Kalenić, F. Vučemilović, Š. Strikoman, J. Krpan, G. Pavelić, A. Zelmanović i dr.).

\section{Omladinski tisak i novi pristup novinskoj fotografiji}

Središnju ulogu u inauguraciji novih glazbenih obrazaca imao je omladinski časopis Polet uz istodobno prihvaćanje njima pripadajućeg izraza na sadržajnom i vizualnom planu. U omladinskom se tisku, poput Poleta i Studentskog lista, počinju javljati teme o kojima do tada nije bilo moguće čitati u novinama toga profila. Naime, smatralo ih se neprimjerenima zbog čega su teme u novinama predstavljale ustaljeno reproduciranje tipiziranih slika društva i stereotipnih formula uzornog omladinca. Nova sadržajna koncepcija Poleta koju su inicirali Ninoslav Pavić i Denis Kuljiš 1978. godine, a realizirao Zoran Franičević kao glavni urednik lista (1979.-1981.), stvorila je komercijalizirane i potrošački orijentirane novine, a to je značilo uvođenje tema atraktivnih mladima: glazbe, koncerata, okupljanja mladih i stvaranje urbane mitologije, seksualnosti, mode, ponašanja, sporta, popularne kulture i društvene scene. ${ }^{12}$ Uvođenje novih tema stvorilo je potrebu i za vizualnim ekvivalentom pisanoj riječi koja će zamijeniti do tada idealizirane i šablonizirane fotografije. Zahvaljujući novoj uredničkoj koncepciji lista te grafičkoj koncepciji povjerenoj Goranu Trbulja$\mathrm{ku}$, koja je uz atraktivni sadržaj inzistirala i na vizualnoj upečatljivosti, spoznata je „,važnost i moć novinske fotografije i mogućnost njezine rječitosti koja je jača od pisane riječi“ “. ${ }^{13}$ Dolaskom Gorana 


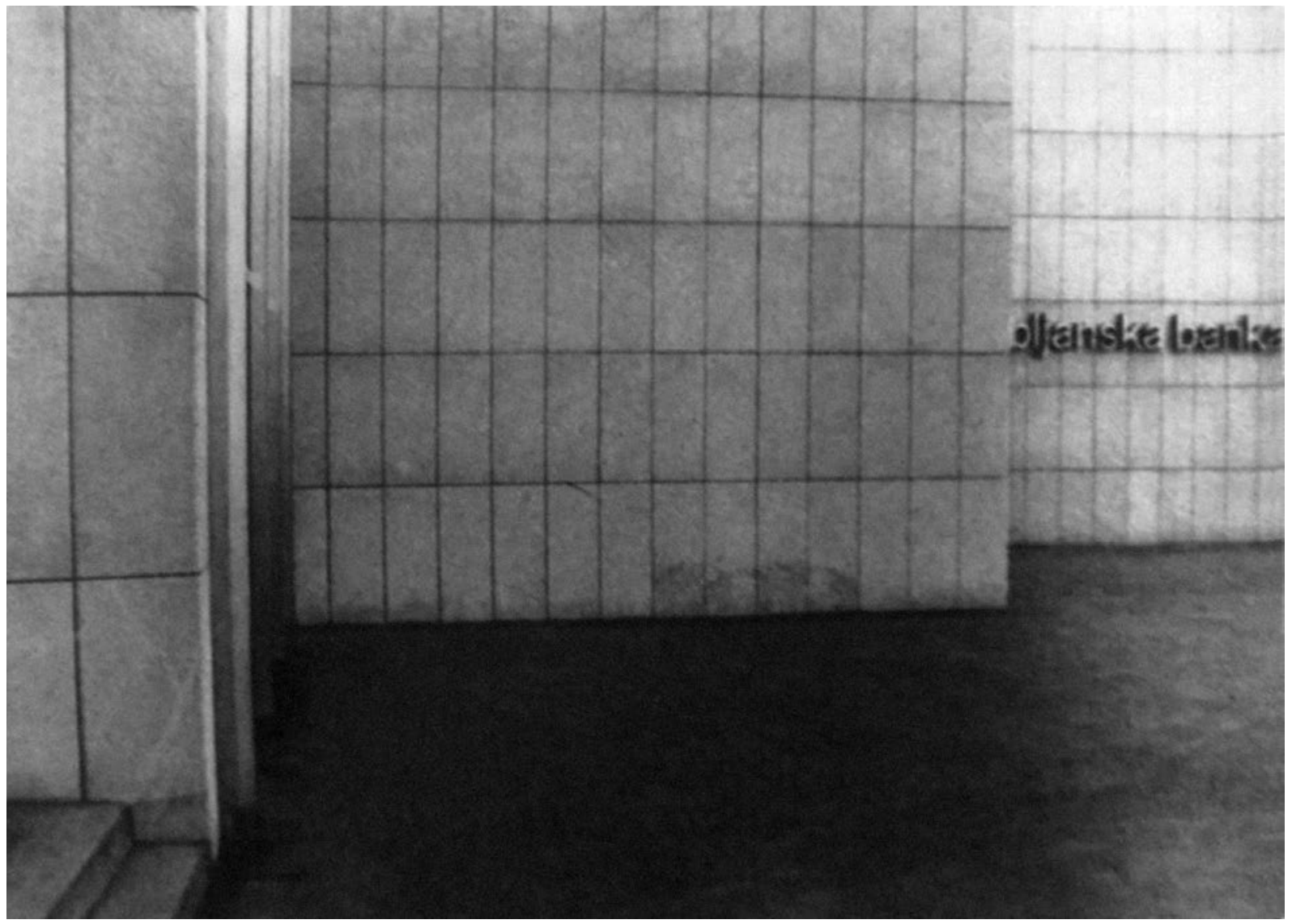

1 Mio Vesović, Ljubljanska banka, 1976. (preuzeto iz: Spot, 8 (1976.), 17)

Mio Vesović, Ljubljanska banka, 1976 (source: Spot, 8 (1976), 17)

Trbuljaka na mjesto grafičkog urednika Poleta (1978.-1981.) u uredništvu je „donesena odluka da uza sve tekstove uz koje treba ići ilustracija, ide originalna fotografija što ju je za tu priliku napravio Poletov fotograf“, a zadatak su u većini slučajeva dobili fotograf i novinar zajedno. ${ }^{14}$ Fotografija je u grafičkoj koncepciji dobila više prostora i po značenju se izjednačuje s tekstom. Preduvjet novom tretmanu novinske fotografije ostvaren je i prijelazom na ofsetni tisak koji je omogućio kvalitetnije reproduciranje fotografija u odnosu na tehniku knjigotiska kojom je do tada tiskan Polet. Specifičnost rada Gorana Trbuljaka kao grafičkog urednika bila je i poštivanje autorstva za koju Slavko Timotijević smatra da je nastala na principu nove umjetnosti 1970-ih. ${ }^{15}$ Fotografije su u novinskoj formi tiskane s crnim rubom, odnosno osvijetljenim rubom filma, a u nekim slučajevima i perforacijom, kao dokaz da je riječ o fotografiji koju je originalno snimio fotograf. Markita
Franulić uz crni rub kao tehničke i stilske osobine fotografije u Poletu navodi i upotrebu bljeskalice, širokokutnog objektiva te Leica-formata filma, a zbog agresivnosti, ikonografije i načina kadriranja Poletovu fotografiju označava likovnom verzijom novog vala u Hrvatskoj. ${ }^{16}$

Novi tretman fotografije u Poletu, a poslije i u Studentskom listu, formirao je platformu za prezentiranje fotografskog rada mladih, većinom neafirmiranih fotografa koji tu mogućnost nisu imali u okviru tadašnjih praksi promoviranja fotografske produkcije. Izložbeni je sustav bio opterećen tradicionalnim podjelama fotografije na umjetničku i dokumentarnu (life-) fotografiju. ${ }^{17}$ Novi fotografski senzibilitet mlade generacije fotografa u novinskoj je fotografiji, osim njezine mogućnosti da dokumentira, prepoznao i umjetničku vrijednost u izražavanju stava prema onome što se fotografira čime je stvoren višak značenja, odnosno autorska i umjetnička nadgradnja. Stimuliranje čitave generacije fotografa, pojava novih tema i interesa, njezina nezainteresiranost za izložbenu aktivnost te afirmiranje isključivo u domeni novinske fotografije, stvorilo je nužnost da se ta pojava $u$ povijesti hrvatske fotografije promotri zasebno što je rezultiralo javljanjem spomenutih termina, ali i generacijskim izdvajanjem tih fotografa kao 
„četvrte generacije zagrebačkih fotografa“.. ${ }^{18}$ Spomenutu je generaciju Goran Trbuljak predstavio na 14. salonu mladih 1982. godine kao „generaciju mladih, zdravih, neopterećenih fotografa koji puno stvarnije sudjeluju u svojoj sredini radom $u$ novinama“, pritom govoreći o M. Vesoviću, I. Posavcu, A. Zelmanoviću, J. Krpanu, G. Pipi Paveliću, F. Vučemiloviću, D. Kaleniću i Š. Strikomanu. ${ }^{19}$ Prema Goranu Trbuljaku, riječ je o fotografima za koje je karakteristično „da su njihove fotografije načinjene brzim strogim okom čiji su komentari (...) u rasponu od duhovite opservacije, lagane ironije do sarkazma i stroge kritike““.20

\section{Vesovićeve fotografije nastale za potrebe tiska}

Vesović se fotografijom počeo baviti u Fotoklubu Zagreb, a iskustvo u novinama stekao je u Studentskom listu gdje kao fotograf radi od 1976. godine, a sljedeće godine i kao urednik fotografije. S radom u Poletu započinje 1977. godine. Uz Polet i Studentski list, Vesović je svoje fotografije objavljivao u časopisima i novinama Start, Svijet, Danas, Quorum, Pitanja, Vjesnik, itd. ${ }^{21} \mathrm{Uz}$ angažman u novinama, Vesović istodobno pohada i studij filmskog snimanja na Akademiji za kazalište, film i televiziju, u klasi Nikole Tanhofera, a u namjeri da prijateljstvo s Akademije profunkcionira kao studio, godine 1979. s Ivanom Posavcem osniva „Meko okidanje“. ${ }^{22}$ Iako su u razdoblju od 1985. do 1989. godine u suradnji oblikovali naslovnice časopisa Danas, „Meko okidanje“ ipak ostaje tek naziv za ovaj autorski tandem koji djeluje bez zajedničkog programa. ${ }^{23}$ Unatoč tomu, abrevijacija „MO“ koju dodaju potpisima fotografija objavljenih u novinama postaje interpretativni okvir njihovim fotografijama: u tematskom pogledu izražava afinitet prema aktu i erotičnosti te fotografiranju lica iz svakodnevne okoline, a u tehničkom korištenje širokokutnog objektiva i bljeskalice te mekom načinu snimanja koje se tim tehničkim pomagalima postiže. ${ }^{24}$

Većina autora koji su pisali o Vesovićevoj novinskoj fotografiji redovito uspoređuju njegov rad prije i poslije iskustva s novom grafičkom i uredničkom koncepcijom Poleta te ističu upravo rad u Poletu kao formativno i afirmativno razdoblje. Goran Trubljak tako ga 1980. godine najavljuje kao „dečka koji najviše obećaje“, ${ }^{25}$ a Davor Matičević povodom samostalne izložbe 1988. godine ističe da „Vesović više nije dečko koji obećaje, već adolescent, ako ne i afirmirani fotograf “. ${ }^{26}$ Mirjana Šigir u osvrtu na istu izložbu Vesoviću priznaje
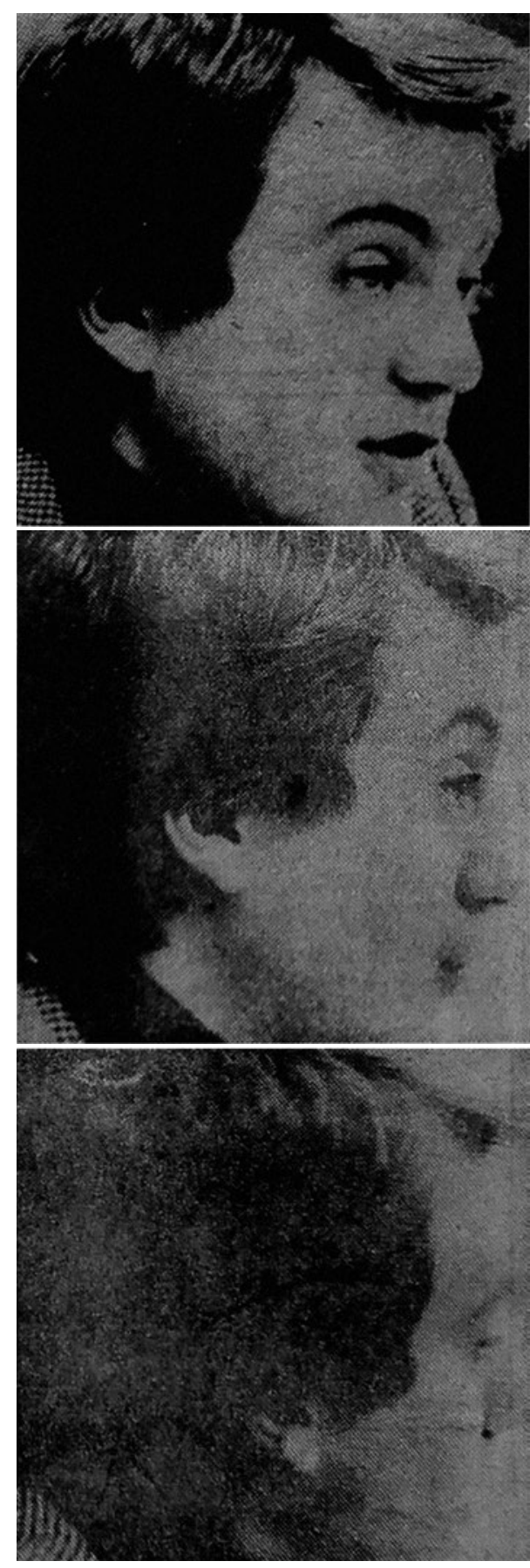

2 Mio Vesović, Ivan Matija, 1978. (preuzeto iz: Polet, 54 (1978.), 13)

Mio Vesović, Ivan Matija, 1978 (source: Polet, 54 (1978), 13)

3 Mio Vesović, Iz foto-intervjua s Momom Kaporom, 1978. (preuzeto iz: Polet, 73 (1978.), 13)

Mio Vesović, From the photo-interview with Momo Kapor, 1978 (source: Polet, 73 (1978), 13) 


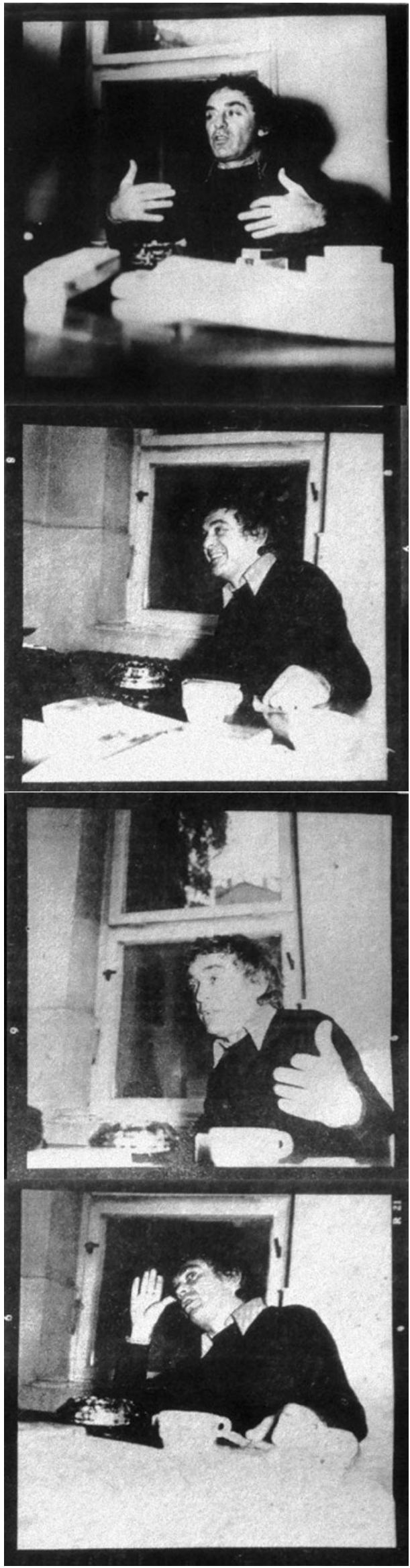

,zanatsku razinu i moderno kadriranje i nekoliko fotografija koje ga najavljuju kao vrsnog fotografa potvrđujući time mišljenje o njegovoj nadarenosti“..27 Utjecaj Poletove fotografije na Vesovićev rad uočava i Markita Franulić nalazeći utjecaje u estetici, temama i uredničkom tretmanu fotografije, no ističe kako je o izrazu upitno govoriti jer Vesović i prije Poleta nije snimao po šabloni. ${ }^{28}$ $\mathrm{Na}$ početku studija filmskog snimanja Vesovićev rad predstavljen je u osmom broju časopisa Spot 1976. godine snimkom detalja zgrade Ljubljanske banke koja, prema mišljenju Markite Franulić, predstavlja fotografiju koja je u to vrijeme vrijedila kao umjetnička i izložbena (sl. 1). ${ }^{29}$ Po uzoru na slikarstvo, opterećena je upotrebom geometrizma (odnosom vertikala i horizontala) u težnji za stvaranjem apstraktnih formi u čemu se promišljanje ljepote javlja kao glavna preokupacija. Dvanaest godina kasnije, 1988., na njegovoj samostalnoj izložbi bile su zastupljene isključivo life-fotografije, ${ }^{30}$ čime je stvoren odmak od fotografske estetike apstrakcije kojoj se suprotstavljaju, kako piše Davor Matičević u tekstu izložbe, „igre s ružnim modelima i odbojnim motivima “. ${ }^{31}$ Promjenu stava prema novinskoj fotografiji Markita Franulić promatra i kroz iskustvo Vesovića kao urednika fotografije Studentskog lista tijekom 1977. godine kada uočava maćehinski odnos prema fotografiji i kasnije, tijekom 1983., nakon iskustva u Poletu s Goranom Trbuljakom te u Studentskom listu s Borom Ivandićem, kada fotografiji daje više prostora i veće značenje. ${ }^{32} \mathrm{~S}$ druge strane, Vesović „Poletovu fotografiju“ smatra „,̌istom izmišljotinom“ te navodi kako je riječ „o ljudima koji su jedno vrijeme radili skupa, a onda su otišli svatko svojim smjerom". ${ }^{33}$

Koliko god bila podijeljena mišljenja o stavljanju zajedničkog nazivnika „Poletova fotografija“ mladoj generaciji fotografa, sigurno je kako je utjecaj nekoliko važnih faktora - estetike vremena, grafičke (Gorana Trbuljaka kao grafičkog urednika) i uredničke koncepcije Poleta i poslije Studentskog lista - omogućio mladoj generaciji fotografa da izraze interes prema reportažnoj fotografiji. ${ }^{34}$ Vesović je tijekom 1980-ih razvio fotografski senzibilitet prema socijalnim temama - portretima i aktovima, fotointervjuima i fotoreportažama. S nekoliko „snimaka s koncerata koje nisu njegov fah“ 35 (Queen, De Lucía, McLaughlin i Coryell, Bijelo dugme, The Human League), pokazao je i interes za žanr rock-fotografije koja svoje začetke na ovim prostorima duguje upravo Poletovoj redakciji. ${ }^{36}$ 


\section{Portreti}

Budući da su intervjui bili stalnom rubrikom $\mathrm{Po-}$ leta, Starta i Studentskog lista, Vesović je od početka fotografskog rada pokazivao afinitet prema temi portreta, a tijekom desetljeća stvorio je specifičan vizualni jezik toga fotografskog žanra. Pred Vesovićevim objektivom našli su se političari (I. Matija, dr. V. Tupurkovski itd.), sportaši (M. Parlov, D. Jurčić, M. Novosel, M. Šarović i dr.), umjetnici (B. Bućan, S. Lupino, G. Trbuljak, A. Augustinčić, V. Richter, M. Bijelić, M. Ilić, K. Harring itd.), kulturni djelatnici (D. Matičević, M. Solar, V. Maleković), glumci i redatelji (M. Nadarević, V. Mimica, K. Papić, R. Grlić, D. Vukotić, V. Bulajić, itd.), novovalni glazbenici (B. Štulić, D. Dvornik, Zabranjeno pušenje, Đ. Novković, vis Idoli, Šarlo akrobata i dr.), ali i lica onkraj estrade i establišmenta 1980-ih, iz sfere svakodnevnog života - radnici, omladina i duševni bolesnici. ${ }^{37}$ U prvim godinama angažmana na području novinske fotografije poštuje standardni tip portreta koristeći varijantu ,tri osnovne točke gledišta snimanja portreta: anfas, profil i poluprofil“", ${ }^{38}$ kao što je to u slučaju portreta Ivana Matije objavljenih u Poletu br. 54 iz 1978. ili portreta Ane Sukić u br. 61 iz iste godine (sl. 2).

Ubrzo razvija tendenciju fotografskog portretiranja u sekvencama bilježeći geste i ponašanje sugovornika s ciljem njihove karakterizacije kao osoba specifične naravi ili naravi koju uočava te interpretira prema ideji „registriranja promjene izgleda zbog promjene stanja“ (sl. 3). ${ }^{39} \mathrm{Kod}$ snimanja portreta često smješta fotografiranu osobu na rub fotografije i obuhvaća pozadinu. Time okolina fotografiranog objekta dobiva novu, deskriptivnu ulogu dodatne interpretacije i individualizacije, zbog čega je snimanje često smješteno u ambijent koji je specifičan karakteru fotografiranog pojedinca. Vesović je tako umjetnike i kustose snimao ispred umjetničkih djela (sl. 4a, 4b), sportaše s pripadajućim rekvizitima njihove discipline (sl. 4c), redatelje i glumce ikonografski obilježene filmom (sl. 4d) ili imitirajući filmsko osvjetljenje kao u slučaju portreta Mustafe Nadarevića (sl. 4e). Pozadina često ima i ulogu statementa - Vesović je tako vizualne protagoniste punka i novog vala Gorana Trbuljaka i Mirka Ilića fotografirao ispred bijele pozadine, čime je stvoren ekvivalent vizualnoj estetici glazbenih videa punka i novog vala (sl. 5a, 5b). Kod portreta glazbenika Vesović njeguje jaki kontrast karakterističan za svjetsku punk i novovalnu fotografiju. Registrira ih $\mathrm{u}$ 4a Mio Vesović, Bijelić na svojoj izložbi u GSU na Katarininom trgu, Zagreb, 1984. (preuzeto iz: Polet, 267 (1984.), 6-7)

Mio Vesović, Bijelić at his exhibition in the Gallery of Contemporary Art at St Catherine Square, Zagreb, 1984 (source: Polet, 267 (1984), 6-7)

4b Davor Matičević $i$ Boris Bućan na Venecijanskom biennalu 8. 6.1984. 1984. (preuzeto iz: Polet, 277 (1984.), 12-13)

Davor Matičević and Boris Bućan at the Venice Biennale, 8 June 1984, 1984 (source: Polet, 277 (1984), 12-13)

4c Dražen Marović, 1980. (preuzeto iz: Polet, 120 (1980.), 20)

Dražen Marović, 1980 (source: Polet, 120 (1980), 20)

4d Krsto Papić, 1987. (preuzeto iz: Polet, 366 (1987.), 8)

Krsto Papić, 1987 (source: Polet, 366 (1987), 8)

4e Mustafa Nadarević, 1987. (preuzeto iz: Polet, 376 (1987.), 25)

Mustafa Nadarević, 1987 (source: Polet, 376 (1987), 25)

5a Mio Vesović, Goran Trbuljak, Velika Gorica, 1980. (preuzeto iz: Studentski list, 763 (1980.), 8)

Mio Vesović, Goran Trbuljak, Velika Gorica, 1980 (source: Studentski list, 763 (1980), 8)

5b Mirko Ilić, 1979. (preuzeto iz: Polet, 105 (1979.), 21)

Mirko llić, 1979 (source: Polet, 105 (1979), 21)

6a Mio Vesović, Branimir Johnny Štulić, 1982. (preuzeto iz: Studentski list, 799 (1982.), 3)

Mio Vesović, Branimir Johnny Štulić, 1982 (source: Studentski list, 799 (1982), 3)

6b Branimir Johnny Štulić, 1982. (preuzeto iz: Polet, 188 (1982.), naslovnica, dupli format)

Branimir Johnny Štulić, 1982 (source: Polet, 188 (1982), cover page, spread) 

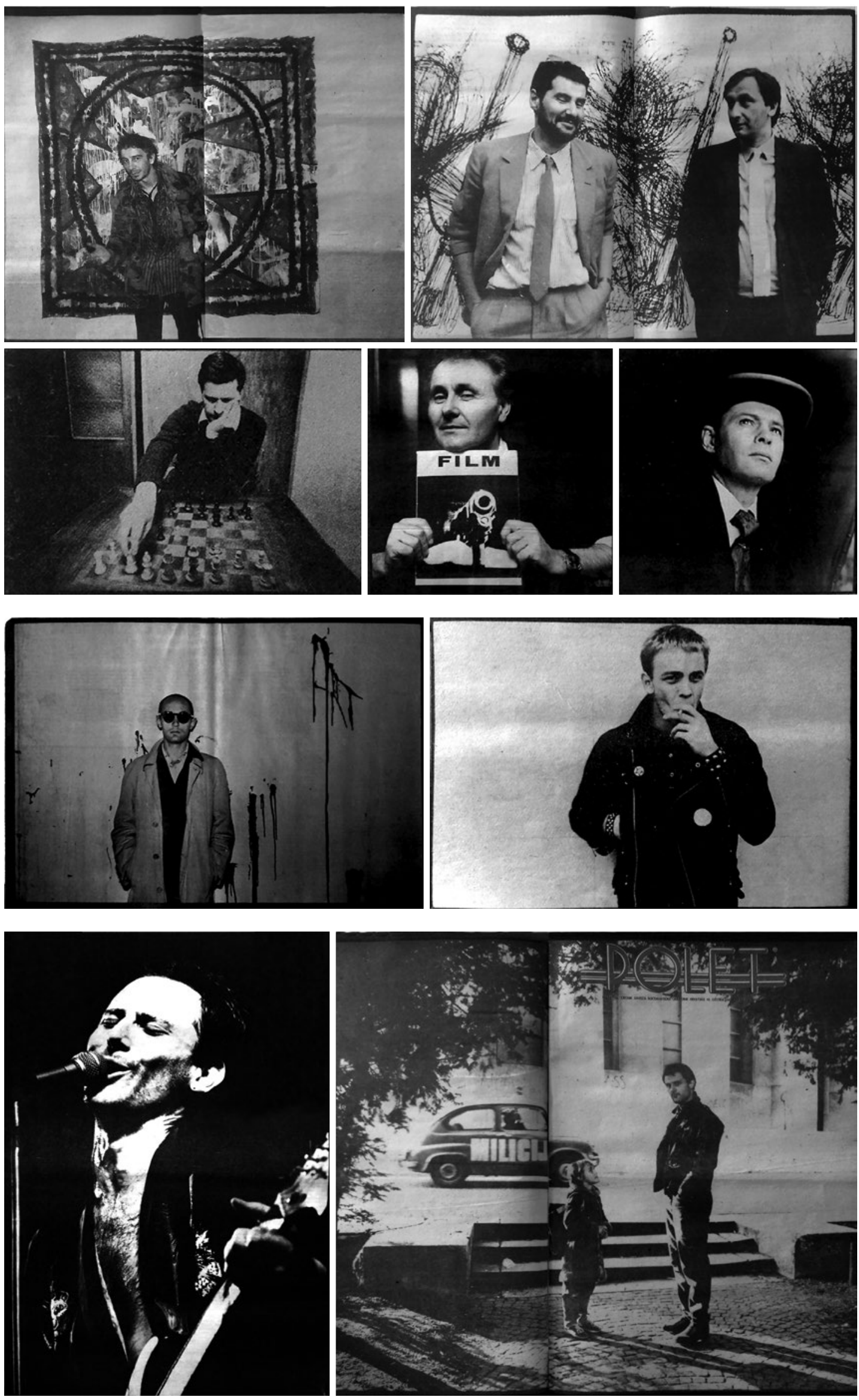
trenucima ekstaze stvarajući tako svojevrsni psihogram (sl. 6a). Tendencija je to koju je pokrenula engleska fotografkinja Pennie Smith fotografijom Paula Simonona, gitarista grupe The Clash, koja je reproducirana na naslovnici njihova albuma London Calling te svjedoči o međusobnoj povezanosti različitih oblika izražavanja unutar kulture punka i novog vala. Slučaj je to i u Vesovićevu fotografskom opusu s obzirom na to da je fotografija Branimira Johnnyja Štulića objavljena u Poletu 1982. godine postala naslovnicom Azrina albuma Filigranski pločnici iz iste godine (sl. 6b).

Uz registriranje okoline kao komentara, kod Vesovića je prisutna i suprotna tendencija u smjeru minimalizma. U tom slučaju dopušta portretiranoj osobi da bude najizraženija sama sa sobom što često potencira korištenjem širokokutnog objektiva te fotografiranjem iz male udaljenosti zbog čega registrira lice u krupnom planu ili detalju te time stvara autorski komentar: portreti Jože Vlahovića (Polet, br. 94, 1979.), Antuna Augustinčića (Polet, br. 101-102, 1979.) i Milana Bekića (Studentski list, br. $797,1982.) .^{40}$

Specifična kompozicija kadra obilježje je Vesovićevih portreta u kojima je vidljivo poštivanje pravila trećine, najizraženije u fotografiranju u krupnom planu korištenjem širokokutnog objektiva (portret Milana Bekića). To pojednostavljeno pravilo zlatnog reza osnova je kompozicije u fotografiji gdje se točka interesa ne postavlja u sredinu jer ,u tom slučaju motiv koji fotograf snima biva najizraženiji sam sobom a fotografovo iskustvo je najneprimjetnije“. ${ }^{41}$ Čak i kada smješta fotografiranu osobu u sredinu kadra i koristi se srednjim planom, Vesović poštuje pravilo trećine, kao što je to u portretu Vatroslava Mimice (sl. 7a, 7b).

Kod snimanja portreta Vesović često koristi i bljeskalicu kako bi uklonio sjene oko očiju i snimio čisto lice. Osvijetljeno lice nalazi se u jakom kontrastu čime se stvara dojam odvojenosti od pozadine, ali i agresivnosti fotografa prema objektu što ga snima, zbog čega se, posebno u slučaju krupnih kadrova, ovaj postupak može označiti principom koji Slavko Timotijević naziva „flešom među oči do istine“ (sl. 8a). ${ }^{42}$ Izostankom bljeskalice postiže se nenametljivost pozicije fotografa i izostanak odredenih obrazaca ponašanja (poziranja) koji mogu biti izazvani od strane fotografa. U Vesovićevim fotografijama prisutna je i tendencija namjerne greške pri snimanju (fotografija Đorđa Novkovića) registriranjem bljeska u ogledalu koji se redovito izbjegava prilikom korištenja toga tehničkog
$7 a$ (preuzeto iz: Studentski list, 797 (1982.), 5)

Mio Vesović, Milan Bekić, 1982 (source: Studentski list, 797 (1982), 5)

7b Vatroslav Mimica, 1982. (preuzeto iz: Studentski list, 797 (1982.), 27)

Vatroslav Mimica, 1982 (source: Studentski list, 797 (1982), 27)

8a Mio Vesović, Pogodite tko je, 1980 (preuzeto iz: Polet, 121 (1980.), 14)

Mio Vesović, Guess who, 1980 (source: Polet, 121 (1980), 14)

8b Đorde Novković, 1980. (preuzeto iz: Polet, 122 (1980.), 19)

Đorđe Novković, 1980 (source: Polet, 122 (1980), 19)

9a Mio Vesović, Radnici u Gredelju, 1979. (preuzeto iz: Polet, 91 (1979.), 3)

Mio Vesović, Workers in Gredelj factory, 1979 (source: Polet, 91 (1979), 3)

9b Iz fotoreportaže o životu u getu, 1979. (preuzeto iz: Polet, 110 (1979.), 8)

From the photo reportage on life in the ghetto, 1979 (source: Polet, 110 (1979), 8) 

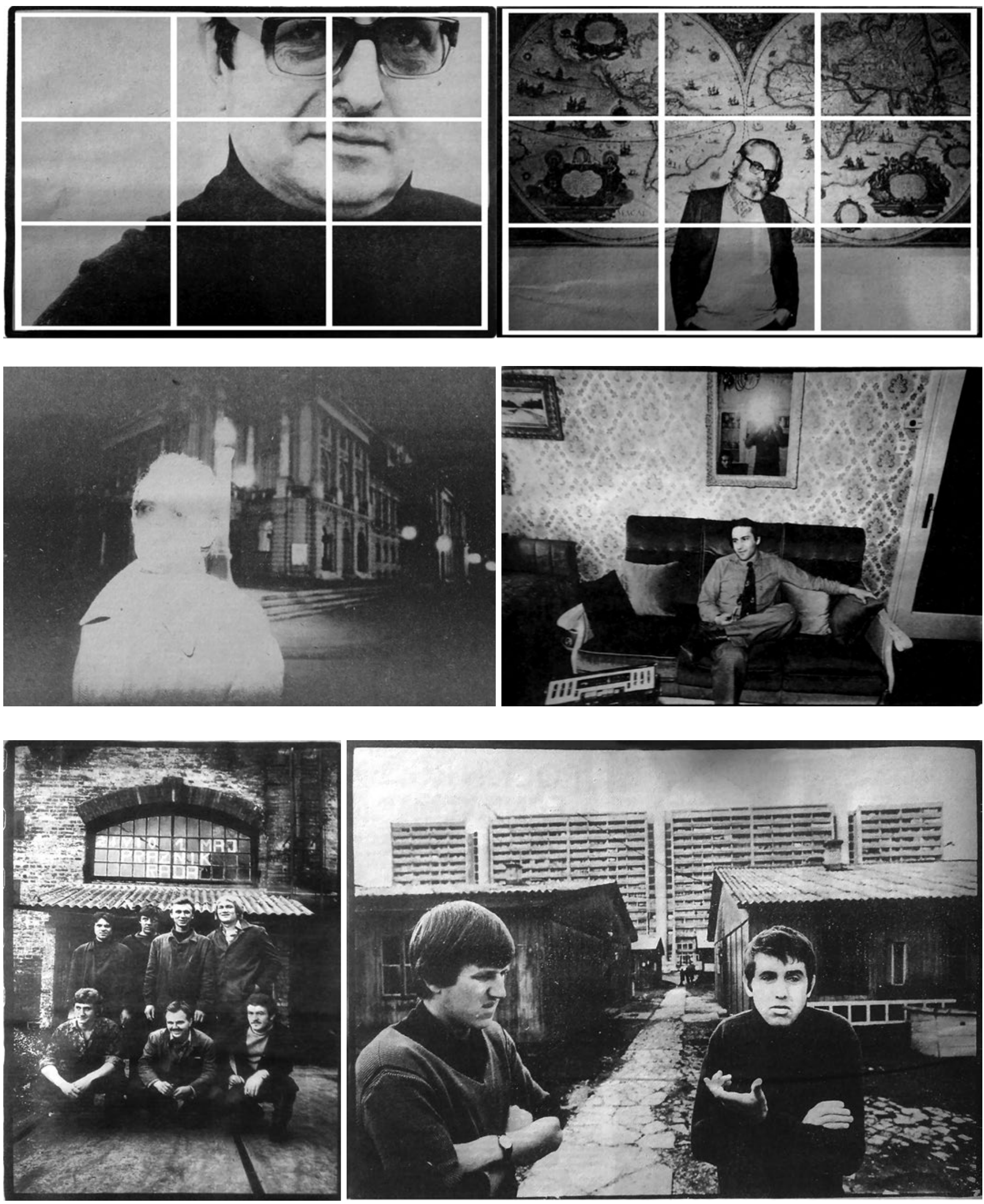


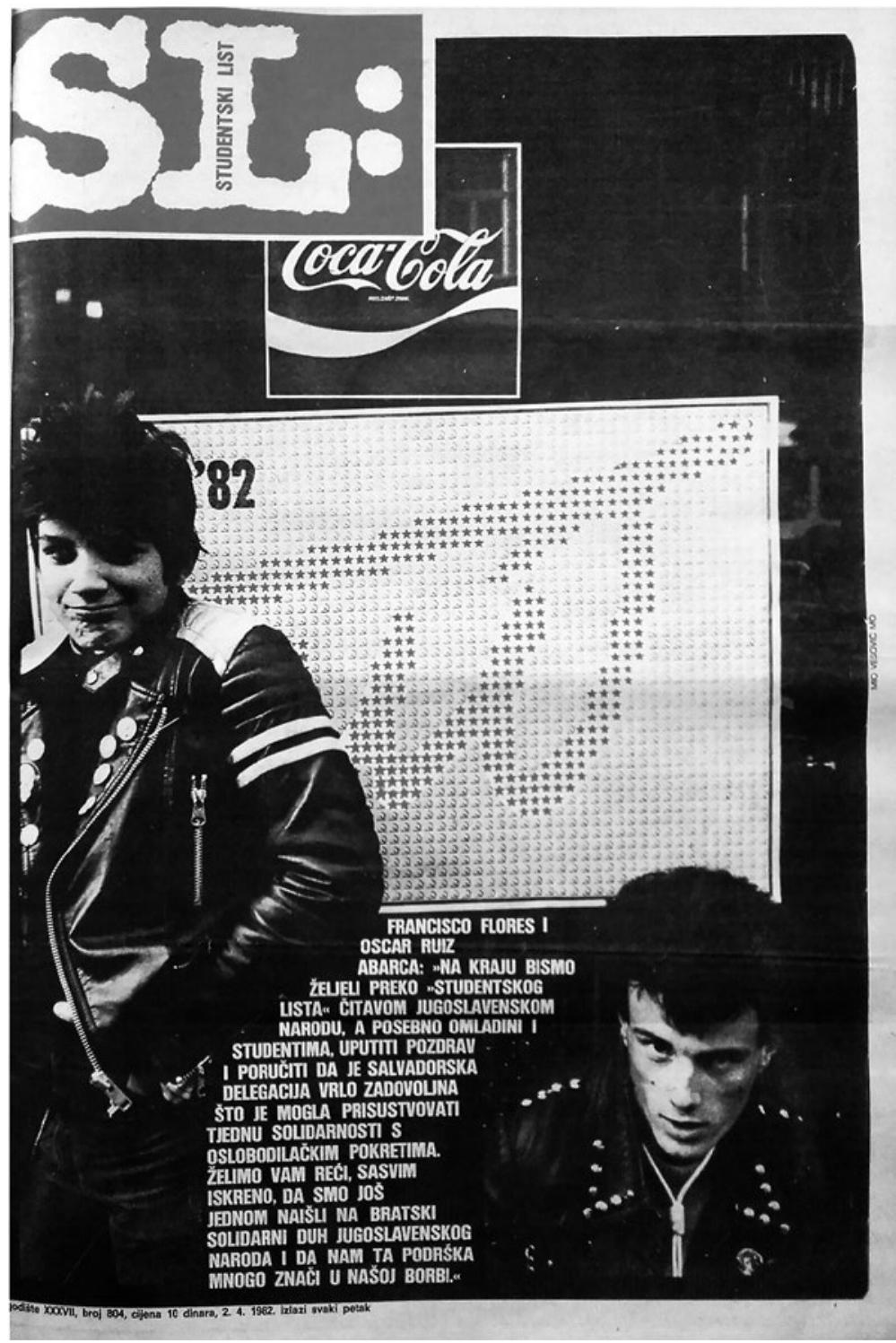

10 Mio Vesović, Punkeri, 1982. (preuzeto iz: Studentski list, 804 (1982.), naslovna stranica)

Mio Vesović, Punkers, 1982 (source: Studentski list, 804 (1982), cover page) pomagala (sl. 8b). Fotograf tako prikazuje vlastitu prisutnost, ali je i istodobno poništava. Poštivanje kompozicijskog pravila trećine, prisutnost ili izostanak bljeskalice, korištenje krupnih i srednjih planova u sekvenci u svrhu izražavanja fotografova iskustva i komentara, u Vesovićevim je fotografijama na interpretativnoj razini moguće iščitati kao intenciju humanizacije koju Davor Matičević ističe nasuprot monumentalizaciji i reprezentaciji. ${ }^{43}$ Vesović je i u snimanju osoba iz svakodnevnog života uveo novine koje se prije svega ogledaju u prisutnosti socijalno-kritičke oštrice - fotografiranjem osoba koje se nalaze na margini društva i koje do tada nisu bile dijelom medijskog prostora i idealizirane slike društva. Novi pristup vidljiv je i u načinu snimanja u kojem je takoder prisutna tendencija individualizacije i personalizacije registriranjem pojedinaca u njihovu okruženju što istodobno omogućuje i konstrukciju ironije - fotografiranje radnika Gredelja ispred ustaljenih parola o radnicima ili stanovnika geta ispred novoizgrađenih stanova čime se jasno upućuje na razmjer sa svakodnevnom praksom (sl. 9a, 9b).44 Novi pristup registriranja stvarnosti vidljiv je i u fotografiranju omladine koja je prestala biti sanjiva i čeznutljiva te je počela pokazivati želju za izražavanjem kritičkog stava prema svijetu unutar kojeg se realizira. ${ }^{45}$ Stoga je i u fotografiji bilo nužno stvoriti novu ikonografiju prikazivanja mlade generacije, uključiti ono što oni podrazumijevaju stvarnim prikazom svijeta i temama koje su do tada bile društveni tabui: seks, droga, alkohol, okupljališta mladih, formiranje supkulture i pripadajućih joj simbola - odijevanja i obrazaca ponašanja (sl. 10).

\section{Akt}

U povijesti je akta kao umjetničke vrste postojala jasna distinkcija što je uvodi Kenneth Clark izmedu golog (engl. naked) i nagog (engl. nude) tijela. ${ }^{46}$ Golo tijelo definirano je kao „tijelo lišeno odjeće koje u javnosti izaziva neprijatne asocijacije“. ${ }^{47}$ Zbog definiranih socijalnih stavova o golom tijelu, smatra Norbert Elias, javljaju se „osjećaji srama i mučnine kao unutarnji strah od samih sebe i oblik samosvladavanja nagona“..48 Proizvodnja i regulacija straha ovisna je o kolektivnom sustavu razmišljanja u kojima stid i osjećaj mučnine pojedincu predstavljaju zabranu, dok nago tijelo kao umjetničko djelo ne sadrži takve konotacije. ${ }^{49}$ Razlog je tomu što golo ljudsko tijelo, kako smatra Kenneth Clark, nikada nije direktno 
transponirano u umjetničko djelo, nego podrazumijeva univerzalne estetske kategorije čime se nadilaze socijalni stavovi o golom tijelu..$^{50} \mathrm{No}$, već s početkom 20. stoljeća Frances Borzello uvida da dolazi od „ogoljavanja nagog tijela“ koje se u drugoj polovini stoljeća počinje poimati kao deklariranje slobode od društvenih normi, individualiziranje ljepote, propitivanje rodnih uloga i seksualnosti čime postaje medij za stvaranje novog identiteta i propitivanje postojećeg. ${ }^{51}$

U hrvatskoj se umjetnosti interes za novo poimanje tijela javlja kasnih 1970-ih kao otpor i subverzija prema dominantnim društvenim normama koje prikaze golog tijela smatraju neprikladnim postojećem sustavu mišljenja. Naglašena senzualnost i potreba individualiziranja svijesti izvan postojećeg sustava vrijednosti i identitetnih formula, prestaju izdvajati „tijelo i umjetnost, već tijelo ulazi u umjetnost“" ${ }^{2}$ kao oblik ,autorovog osobnog govora koji se temelji na prikazivanju vlastitog golog lika ili likova iz okoline“. ${ }^{53} \mathrm{U}$ tom kontekstu formiran je i Vesovićev fotografski senzibilitet i privrženost temi muškog akta, prisutan u novinskoj fotografiji gdje preispituje i provocira društvene stavove o golom muškom tijelu, ali i u samostalnim ciklusima u kojima uspostavlja specifične metafore i asocijacije. ${ }^{54}$ Stoga, fotografije aktova objavljene u novinama zajedno s fotografijama samostalnih ciklusa čine zaokruženu misaonu cjelinu u kojoj Vesović „relativizira odnos javnog i privatnog, individualnog i kolektivnog, pornografskog i erotskog, masovno medijskog i umjetničkog“. ${ }^{55}$

Nova ikonografija svakodnevnog života koja se počinje stvarati u tisku kasnih 1970-ih pokazala je liberalni karakter u pogledu na golo ljudsko tijelo, erotiku i seksualnost unutar sistema čije su vrijednosti bile osjetljive na vizualne i tekstualne manifestacije tih pojmova. Međutim, Slavenka Drakulić-Ilić uočava da je puritanizam službenoga ideološkog diskursa u pogledu na prikazivanje golog tijela pokazivao „dvostruki seksualni moral“ ${ }^{56}$ Dok je žensko tijelo bilo eksploatirano kao atraktivni vizualni materijal, prikazi muškog tijela morali su reproducirati dominantnu poziciju muškarca u kulturi u kojoj je golo muško tijelo dobilo značenje, zaključuje Slavenka Drakulić-Ilić, „ogoljavanja i demistifikacije falusa, odnosno simbola njegove moći“. ${ }^{57} \mathrm{U}$ tom kontekstu, Vesovićeve fotografije muških aktova objavljene u tisku, a time prezentirane širokoj javnosti i sistemu koji je vježbao toleranciju prema prikazivanjima 


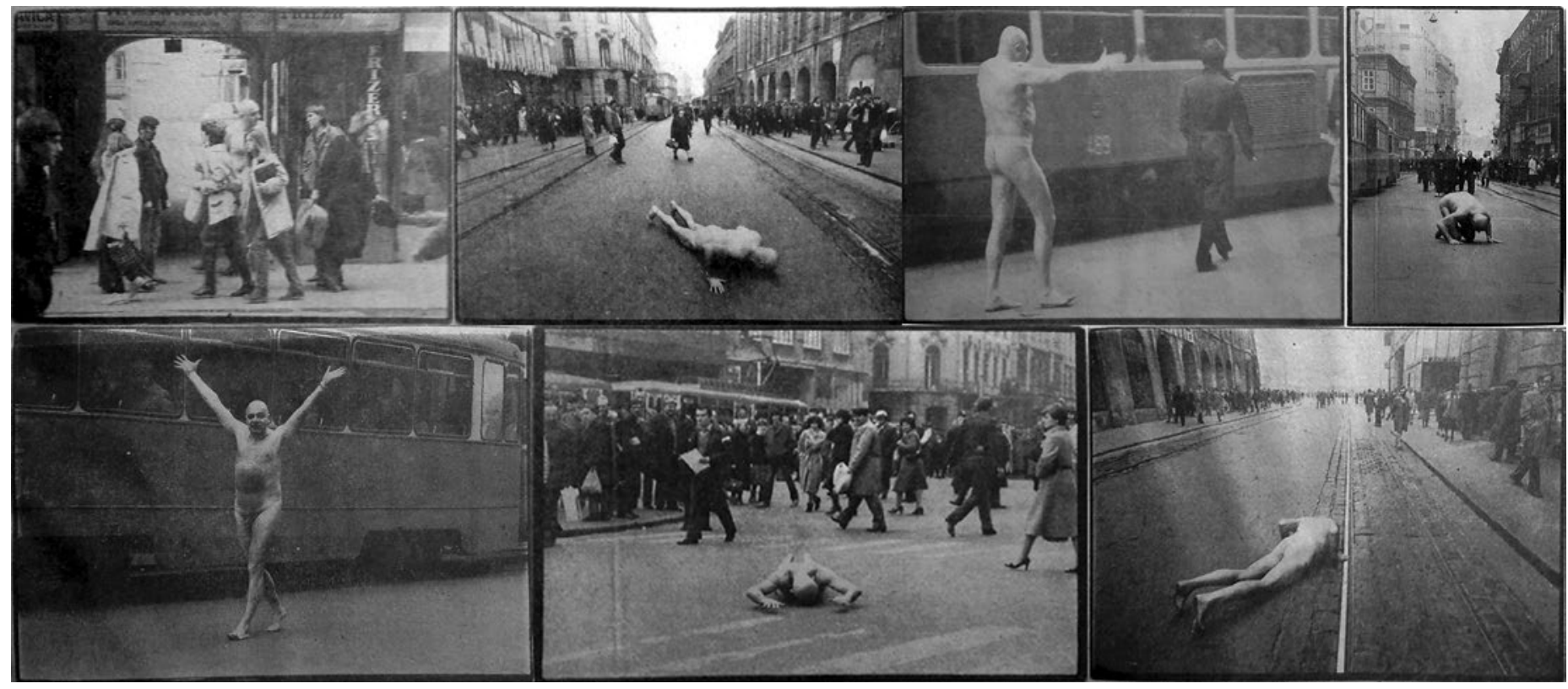

12 Mio Vesović, Zagreb, volim te!, 1981.

(preuzeto iz: Studentski list, 793 (1981.), 15)

Mio Vesović, Zagreb, I love you!, 1981 (source:

Studentski list, 793 (1981), 15)

muškoga golog tijela, suprotstavljaju se društvenim normama te identitetnim formulama kolektivnoga muškog tijela kojima suprotstavlja „kriterije efekta i šoka u iskustvu uobičajenog shvaćanja ljepote“..$^{58}$

Prvi poznati ciklus akta Vesović je objavio u Poletu br. 127 iz 1980. godine. Riječ je o osam fotografija „gol mana“ Šarovića snimljenih za potrebe intervjua objavljenog u Poletu pod naslovom Tip-top izglancan (sl. 11). Ubrzo nakon distribucije, Vesović je zajedno s uredništvom optužen za pornografiju, a sporni je broj povučen iz prodaje i zabranjen. „Nikada do tada“, ističe Željko Krušelj, , , u povijesti hrvatskog i jugoslavenskog tiska nije se dogodilo da nekoj javnoj ličnosti bude, i to višestruko 'izloženo” i spolovilo“. ${ }^{59}$ Šarović je krajem 1970-ih bio popularni golman zagrebačkog kluba (NK Zagreb) te je uživao status onodobne zvijezde. Tomu svjedoči i njegovo „narcisoidno i samosvjesno ekshibicionističko poziranje" svojstveno tom vreme$\mathrm{nu},{ }^{60} \mathrm{u}$ cilju reproduciranja društvene predodžbe o vlastitoj vanjskoj pojavnosti Šminkera, kako su ga zvali. Šarovićevo poziranje, Vesovićeva tendencija da kadrom obuhvati i njegov falus te kasnije reakcije na objavljene fotografije jasno upućuju na kontradiktornost 1980-ih. S jedne strane, vidljiva je prisutnost samosvijesti o vlastitom tijelu, a s druge nužnost reproduciranja društvenih normi u kojoj poseban naglasak stoji na osobama iz javnog života i na novinskim fotografima kojima je povjeren taj zadatak. U toj kontradiktornosti, Vesovićevo „okidanje“ istodobno postaje oslobađanje tijela i oslobađanje fotografa.

Sljedeći Vesovićev ciklus muškog akta predstavljaju fotografije umjetničke akcije Zagreb, volim te! Tomislava Gotovca izvedene 13. studenoga 1981. godine ${ }^{61}$ Ekshibicionističko ponašanje, korištenje tijela kao medija subverzije, izazivanje efekta šoka te reakcije policije kao zaštitnika postojećeg sustava vrijednosti, karakteristični su postupci u poimanju tijela kao momenta preispitivanja identiteta i slobode, a sagledani s Vesovićevim fotografijama 


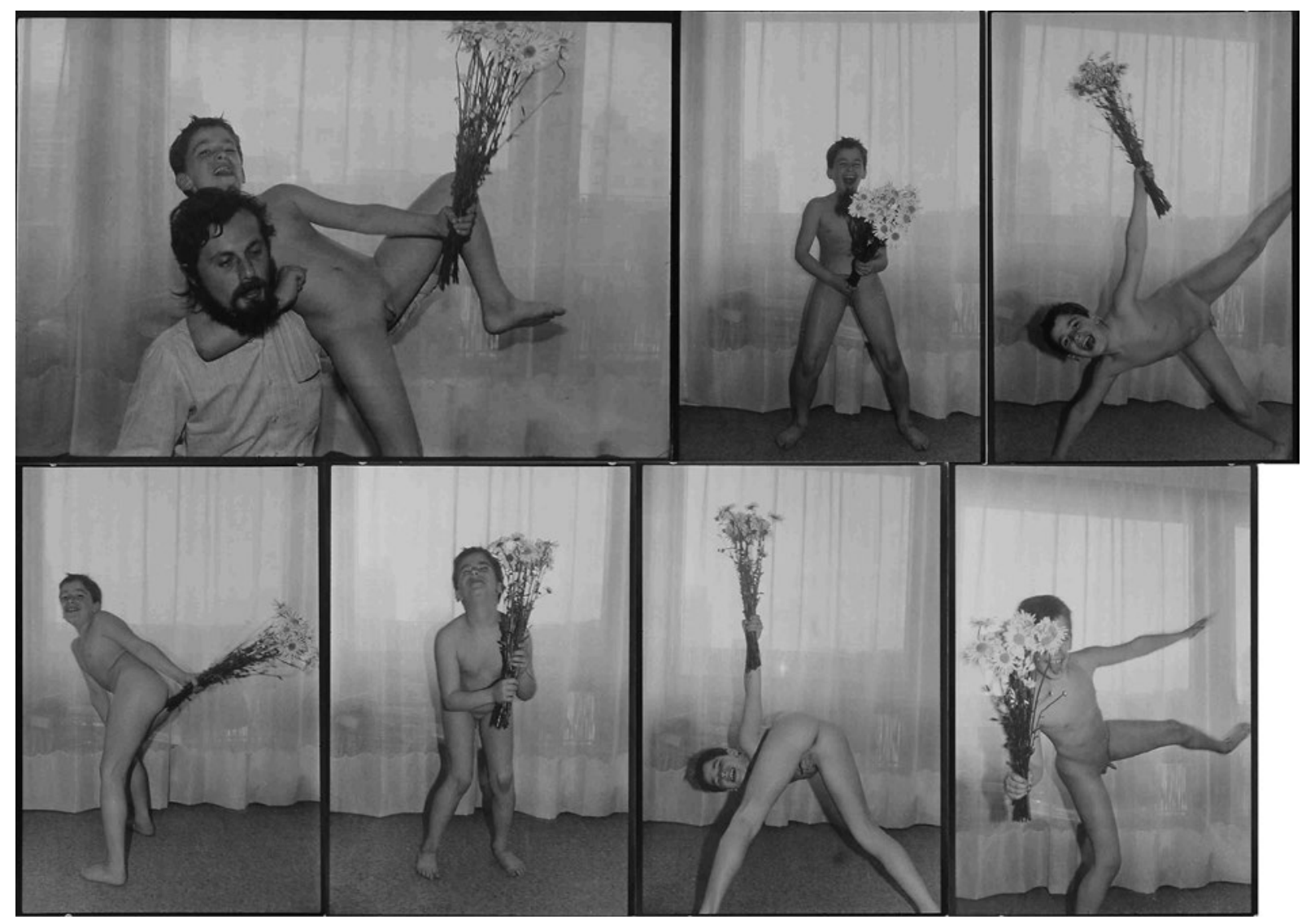

13 Mio Vesović, Za Rexa, 1983. (fotografije ustupio autor)

Mio Vesović, For Rex, 1983 (courtesy of the author)

ilustriraju stav i zajedničko osjećanje stvarnosti svojstveno vremenu 1980-ih. Vesovićeve fotografije objavljene 20. studenoga 1981. godine u Studentskom listu br. 793 integralan su dio akcije, a ne samo fotoreportaža događaja (sl. 12). ${ }^{62}$ Vesović u kadrovima bilježi Gotovčev osmominutni performans, čime primarni fokus postaje ponašanje golog tijela i njegov ulazak u tkivo grada, a reakcije slučajnih prolaznika zabilježene su u drugom planu. Fotografije objavljene u Studentskom listu opskrbljene su „sažetim i, u osnovi, kodiranim tekstom" koji fotografski prikazanoj akciji odreduje radnju, protagonista, vrijeme i prostor. ${ }^{63}$ Time fotografije dobivaju konceptualni pomak i nisu više samo dokument performativne akcije zbog čega je u potpisu objavljenih fotografija autorstvo i Gotovčevo i Vesovićevo, a objavljivanjem u novinama pokazuju i odliku news arta.

Početkom 1980-ih Vesović se posvetio i samostalnim fotografskim ciklusima u kojima je takoder prisutan afinitet prema temi akta. Taj interes nužno ne upućuje na razgraničenje umjetničke i life-fotografije unutar Vesovićeva opusa jer su fotografije ciklusa Za Rexa objavljene kao ilustracija tekstu u Studentskom listu br. 848-849 (1983.), kao i one ciklusa Rosebud u br. 3 (932) (1987.). Ciklus Za Rexa nastao je 1983. godine u Parizu, a riječ je o sekvenci fotografija koje prikazuju igru golog dječaka Aljoše Roksandića s buketom cvijeća u stanu njegovih roditelja. ${ }^{64}$ Fotografije, iako danas kategorizirane kao akt, pokazuju obilježja life-fotografije u kojoj Vesović bilježi događanje pred kamerom: igru golog dječaka koji se u različitim pozama spontano pokazuje (sl. 13). U nevinoj igri dječaka s buketom Vesović specifičnim metaforama i asocijacijama evocira čistoću, nevinost i osjećajnost koje se vežu uz doba djetinjstva. No, buket cvijeća istodobno djeluje i kao „snop šiba, čime uz andeosko, kupidsko, dobrotu i naivnost egzistiraju đavosko, pokvarenost i zloća“, a čin fotografiranja postaje oblik prisvajanja iskustva $\mathrm{i}$ fotografove samospoznaje. ${ }^{65}$ 

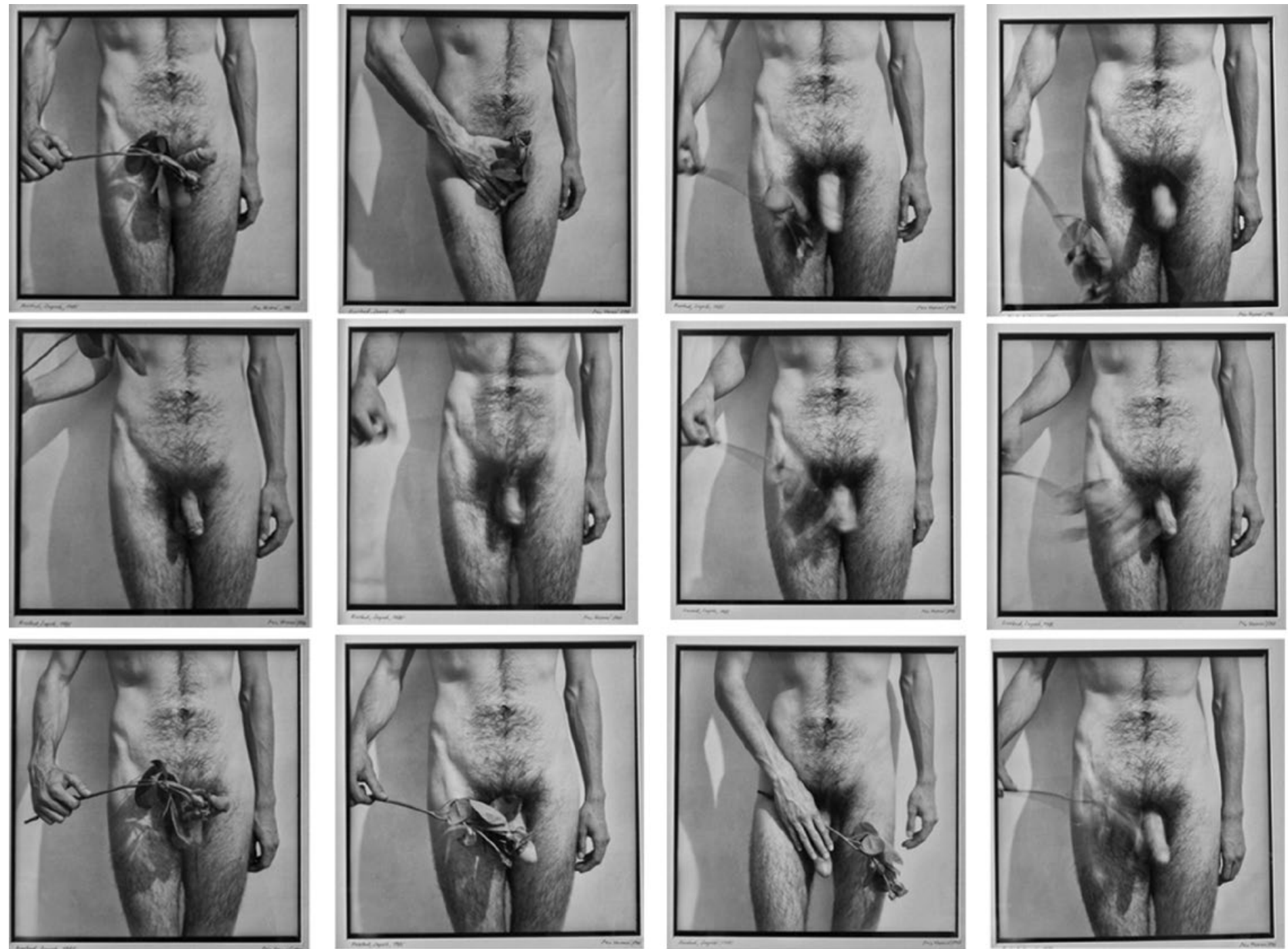

14 Mio Vesović, Rosebud, 1985., Leila Mehulić, Ime ruže (preuzeto iz: Mio Vesović Rosebud II, katalog izložbe, Radnička galerija, Zagreb, 14. 7. - 2. 9. 2015., 20-23)

Mio Vesović, Rosebud, 1985, Leila Mehulić, The Name of the Rose (source: Mio Vesović Rosebud II, exhibition catalogue, Radnička galerija, Zagreb, 14 July - 2 September 2015, 20-23) 
Sljedeći Vesovićev ciklus Rosebud sekvenca je fotografija nastalih 1985. godine koje pokazuju karakteristike kompozitne fotografske priče. U ciklusu Rosebud muško je tijelo kompozicijski određeno na donji dio trupa gdje centralnu poziciju u kadru zauzima falus koji biva uzbuden ružom (sl. 14). Za razliku od prijašnjih fotografija u kojima je prisutna naglašena karakterizacija, fokus na lice i geste, čime se fotografiran motiv na izvjestan način individualizira, Vesović se u ciklusu Rosebud od „individualnog pomiče prema univerzalnom iskustvu“. ${ }^{66}$ Istovremeno, kompozicijom stvara reminiscenciju na kadar filma Lazara Stojanovića Plastični Isus iz 1971. godine, amblematsko ostvarenje jugoslavenskoga crnog vala, u kojem je prvi put prikazan lik golog muškarca, utjelovljenog od strane Tomislava Gotovca. Promatranjem sekvence Rosebud u dva smjera, kako je u izložbenoj koncepciji 1985. godine predložio Goran Trbuljak, stvorena su i dva moguća značenja po uzoru na dvosmislenost pojma Rosebud koji preuzima iz filma Orsona Wellesa Građanin Kane: u smjeru senzibiliziranja falusa ružom gdje se izostavlja trenutak užitka i ističe senzibilnost (kako je Vesović i realizirao ciklus), ili u smjeru kažnjavanja ružom nakon postignutog užitka (što predlaže Goran Trbuljak kao drugu mogućnost interpretacije). ${ }^{67}$

\section{Fotoreportaže}

Uz portrete i intervjue, Vesovićev čest zadatak bile su i fotoreportaže u kojima nizom fotografija stvara priču o nekom događanju. U tom je fotografskom žanru vidljiv drugačiji pristup u bilježenju priče u usporedbi fotoreportaža iz Studentskog lista objavljenih tijekom 1977. godine i onih iz Poleta, Starta i Studentskog lista, do kojeg dolazi nakon iskustva s njihovom novom tematskom i grafičkom koncepcijom.

Stazama revolucionarnog Zagreba (Studentski list, br. 21-22, 1977.), Index-karavana prijateljstva (Studentski list, br. 23-24, 1977.), Sa svečanog dočeka i ispraćaja štafete mladosti (Studentski list, izv. br., 18. 5. 1977.) primjeri su fotoreportaža koje se tematski i tehničko-stilski razlikuju od kasnijih Vesovićevih radova u tom žanru (sl. 15). U nizu fotografija kojima dokumentira susret studenata iz Zagreba i Beograda, Vesović podudara fabulu i siže toga događaja, bilježeći pritom kronološki najvažnije događaje koji su u tiskanoj formi dodatno opterećeni strogom linijskom koncepcijom prezentiranja te jezičnim formulacijama.
Kasnije Vesovićeve fotoreportaže razlikuju se ponajprije tematski od onih iz Studentskog lista koje objavljuje tijekom 1977. godine. Riječ je o pričama iz svakodnevnog života: U Bistrici se dobro živi (Polet, br. 110, 1979.), Život u getu (Polet, br. 110, 1979.), Reportaža iz Gredelja (Polet, br. 91, 1979.), Reportaža sa otoka Ugljana: Mladi Johnatani (Polet, br. 93, 1979.), Veliki bal Roma (Studentski list, br. 799, 1982.), u kojima Vesović daje svoje viđenje birajući trenutke koje smatra zanimljivima, a koji nisu isključivo ključni u funkcijama razvijanja stvarnog tijeka priče, čime se od dokumentarnog pomiče prema interpretativnom (sl. 16).

Tijekom angažmana na području novinske fotografije Vesović je stvorio specifičan i prepoznatljiv jezik vizualne antropologije fotografijama koje su odraz stava prema životu što ga formira i fotografskim jezikom izražava. Njegove fotografije odlikuje izrazita intuicija i percepcija svijeta koja, materijalizirana u udaru svjetlosti o fotografski film, stvara osobnu priču o vremenu i prostoru u kojima fotograf djeluje. Ovisno o njima, umjetnost mu pruža mogućnost intervencije i komentara svakodnevnog života i stvarnosti toliko bliske mediju fotografije. Svako „meko okidanje“ za Vesovića predstavlja čin neodvojiv od života i umjetnosti. Ta gesta vidljiva je u svakoj fotografiji, kao i u pristupu umjetničkom djelu. Koristeći se upravo konvencijama medija, zadatostima tijela ili motiva koji fotografira, on izvodi performativ: njegova reportažna fotografija ispunjava funkciju, ali i stvara značenje. 


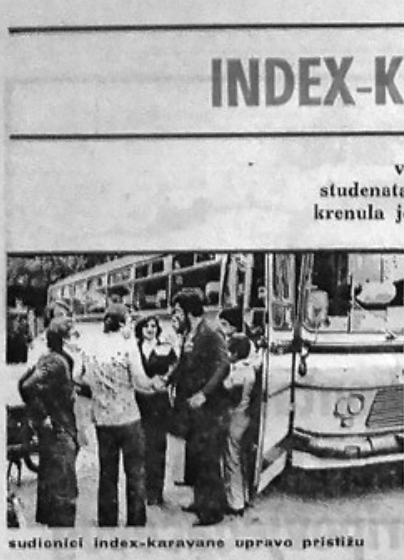

\section{INDEX-KARAVANA PRIJATELJSTVA}

već tradicionalna index-karavana prijateljstva

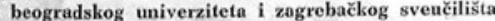

renula je koncem prošlog tjedna: radno, drugarski $\mathrm{i}$ poletno
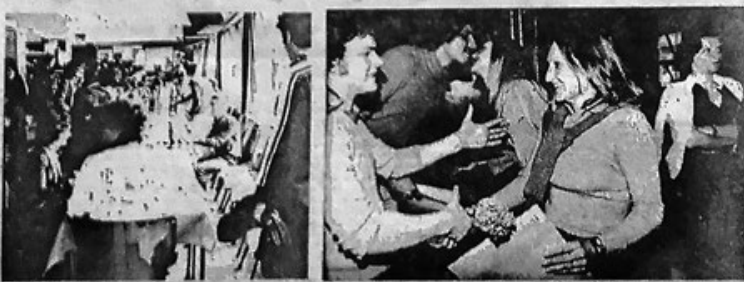

svima orvene karantite
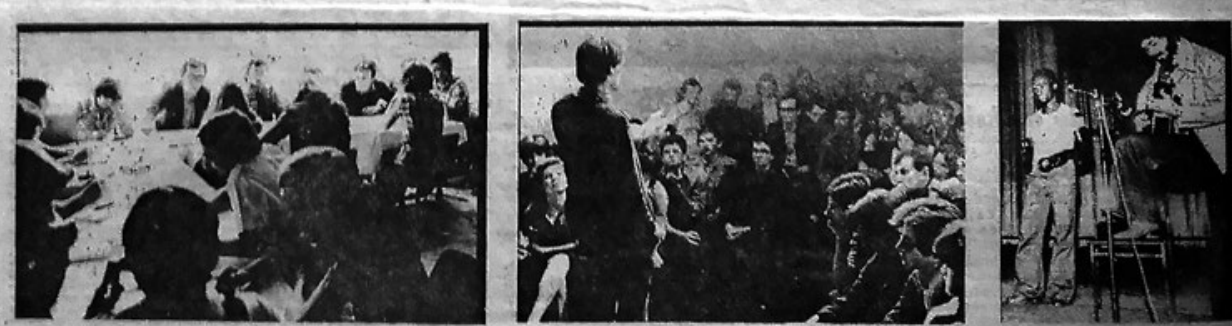

konstifuiranle omladinske radne brigade

na kraju - kulturni program

pripremili: daniel riđički I milisar vesevil

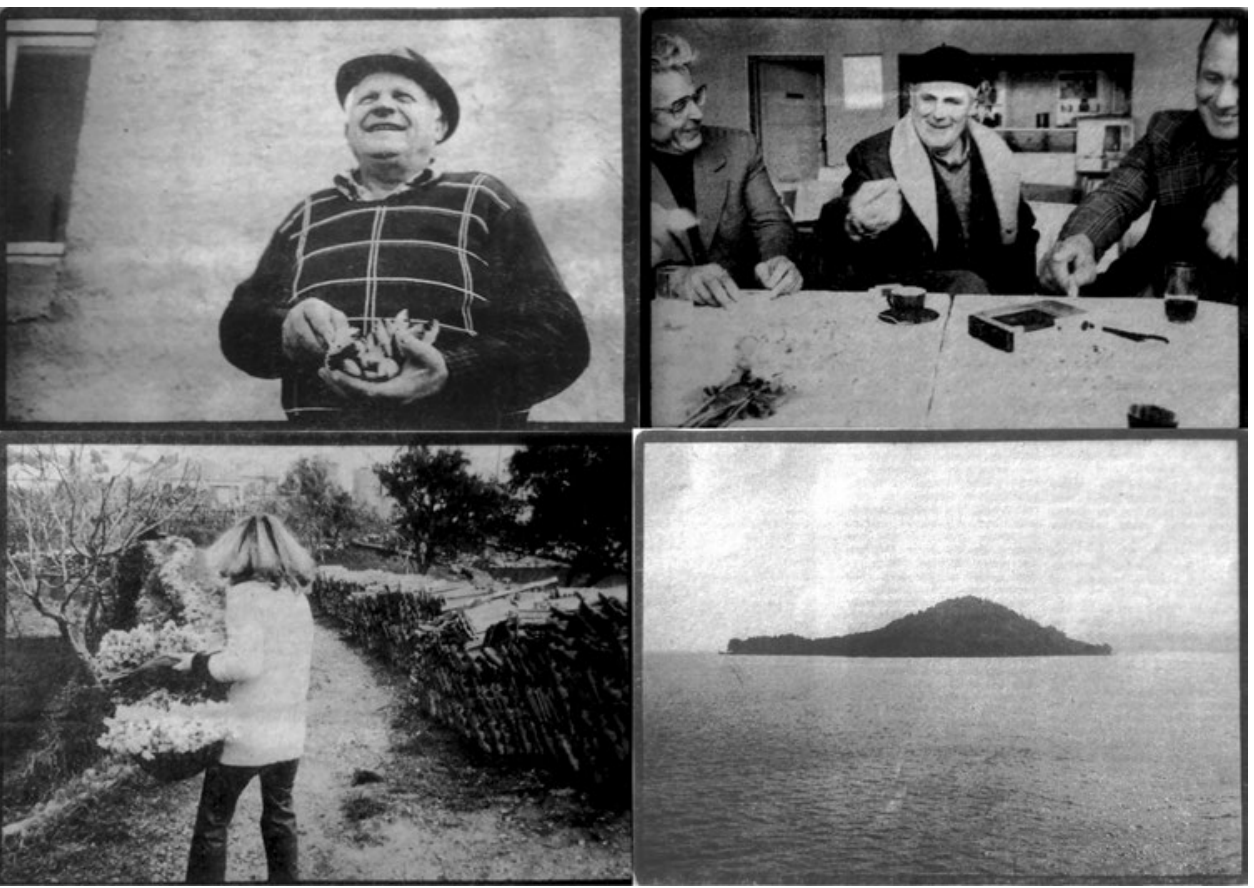

15 Mio Vesović, fotoreportaža o indexkaravani prijateljstva, 1977. (preuzeto iz: Studentski list, 23/24 (1977.), 16)

Mio Vesović, photo reportage on indexcaravan of friendship, 1977 (source:

Studentski list, 23/24 (1977), 16)

16 Mio Vesović, iz fotoreportaže s otoka Ugljana, 1979. (preuzeto iz: Polet, 93 (1979.), 5-6)

Mio Vesović, from the photo reportage from the island of Ugljan, 1979 (source: Polet, 93 (1979), 5-6) 


\section{BILJEŠKE}

1 Termin „nova novinska fotografija“ uvodi vLADIMIR GUDAC u: Nova novinska fotografija, Pitanja: društvo, znanost, kultura, 10/12 (1980.), 2-104. Termin „Nova life-fotografija“ uvodi SLAVKo timotijević u: Fedor Vučemilović: Fotografija i video, katalog izložbe, Srećna galerija, skc, Beograd, 3. - 15. 2. 1984., bez pag. Termin „Poletova škola fotografije“ uvodi SLAVKO TIMOTIJEVIĆ u: Novotalasna fotografija $u$ rock-ključu, u: Drugom stranom: almanah novog talasa SFRJ, (ur.) Milena Petrović, Velimir Ćurgus Kazimir, Istraživačko-izdavački centar sso Srbije, Beograd, 1983., 52-62.

2 Članak se temelji na diplomskom radu Fotografija Mije Vesovića obranjenom na Odsjeku za povijest umjetnosti Filozofskog fakulteta Sveučilišta u Zagrebu 2016. godine pod mentorstvom dr. sc. Lovorke Magaš Bilandžić, doc., u kojem je monografski obrađen Vesovićev opus.

3 Izložbe koje su retrospektivno i cjelovito pristupile prezentaciji Vesovićeva fotografskog opusa priredili su kustosi Davor Matičević i Marina Viculin. Usp.: DAVOR MATIČEvić, Vesović, katalog izložbe, CEFFT, Galerije grada Zagreba, Zagreb, 18 2. - 13. 3. 1988.a; MARINA VICULIN, Mio Vesović: fotografije '76 - 'o3, katalog izložbe, Galerija Klovićevi dvori, Zagreb, 26. 2. - 6. 4. 2003.

O Vesovićevu angažmanu na području novinske fotografije pisano je u člancima i radovima posvećenima novom pristupu i tretmanu novinske fotografije: VLADIMIR GUDAC (bilj. 1), 2-104; MARKITA FRANULIĆ, Poletova fotografija-deset godina kasnije, Život umjetnosti: časopis za pitanja likovne kulture, 45-46 (1989.), 40-53; ZRINKA KUIĆ, Poletova fotografija, diplomski rad, Odsjek za povijesti umjetnosti, Filozofski fakultet Sveučilišta u Zagrebu, Zagreb, 2005 Uz stručnu literaturu, organizirane su i brojne izložbe u okviru kojih su bili predstavljeni Vesovićevi novinski radovi: Nova fotografija 3, katalog izložbe, (ur.) Dimitrije Bašičević, CEFFT, Galerije grada Zagreba, Zagreb, prosinac 1979. - siječanj 1980., Salon Muzeja suvremene umjetnosti, Beograd, ožujak - travanj 1980., Razstavni salon Rotovž, Maribor, srpanj 1980.; 14. salon mladih, katalog izložbe, (ur.) Slavomir Drinković, Umjetnički paviljon, HDLU - Prostor proširenih medija, Zagreb, 2. - 16. 12. 1982.; SLAVKO TIMOTIJEvić, Mio Vesović/MO - Meko okidanje, katalog izložbe, Srećna galerija, skc, Beograd, veljača 1985.; Osamdesete! Slatka dekadencija postmoderne, katalog izložbe, (ur.) Feđa Vukić, Branko Kostelnik, HDLU, DIPK, Zagreb, 10. 4. - 10. 5. 2015.; Krivo srastanje, katalog izložbe, (ur.) Leila Topić, Muzej suvremene umjetnosti, Zagreb, 7. 7. - 9. 8. 2015. O samostalnim fotografskim ciklusima nastalima tijekom 1980-ih pisali su: DAVOR MATIČEvić, Rosebud (pupoljak) Mio Vesović, katalog izložbe, CEFFT, Galerije grada Zagreba, Zagreb, 11. 4. - 30. 4. 1985.; ZVONKO MAKOVIĆ, U ime ruže, Život umjetnosti: časopis za pitanja likovne kulture, 45-46 (1989.), 54-55; DAVOR MATIČEVIĆ, Neki primjeri akta kao teme u hrvatskoj umjetnosti od Bukovca do Gotovca i dalje, $\mathrm{u}$ : Neki primjeri akta kao teme u hrvatskoj umjetnosti od Bukovca do Gotovca i dalje, katalog izložbe, (ur.) Davor Matičević, Galerija suvremene umjetnosti i CEFFT, Galerije grada Zagreba, Zagreb, 12. 5 - 12. 6. 1988.b, bez pag.; BOJANA PEJIĆ, Negotiating Private Spaces, u: Gender check: femininity and masculinity in the art of Eastern Europe, katalog izložbe, (ur.) Bojana Pejić, Museum Moderner Kunst Stiftung Ludwig Wien, Beč, 13. 11. 2009. - 14. 2. 2010., Zacheta National Gallery of Art, Varšava, 19. 3. - 13. 6. 2010., Verlag der Buchhandlung Walther König, Köln, 143-227; LEILA MEHULIĆ, Ime ruže, u: Mio Vesović Rosebud II, katalog izložbe, Radnička galerija, Zagreb, 14. 7. - 2. 9. 2015., 4-27.

4 Vesovićeve fotografije uvrštene su u funduse Muzeja suvremene umjetnosti u Zagrebu, Moderne galerije u Zagrebu,
Muzeja za umjetnosti i obrt u Zagrebu te Galerije umjetnina u Splitu.

5 Vesović je u Studentskom listu fotografije objavljivao od 1976. do 1990. godine, u Poletu od 1977. do 1990., u tjedniku Danas od 1982. do 1991. i tijekom 1992. godine kada je formirana nova koncepcija lista Novi Danas te u magazinu Start od 1987. do 1990. godine (podaci na osnovi uvida u godišta spomenutih tiskovina). Nakon 1990. godine Vesović nastavlja s povremenim objavljivanjem fotografija u novinama, no primarno se posvećuje samostalnim fotografskim projektima jer ,polet“ fotografije što se javlja u omladinskom tisku tijekom 1980-ih do kraja desetljeća jenjava, a pozicija i tretman fotografije vratili su se ranijoj praktičnoj i informativnoj upotrebi. Vesović već 1988. godine ,priznaje kako je entuzijazam mlade generacije fotografa brzo splasnuo jer nje zapravo nema u našim novinama, a nema je, po njegovom mišljenju zato što nema za njom potrebe, nema prostora na kojem bi se objavila, odnosno prezentirala tako da sama fotografija za sebe govori vlastitim jezikom, a nema ni novca kojim bi se platila“. Prema: MIRJANA ŠIGIR, Okviri darovitosti, Vjesnik Socijalističkog saveza radnog naroda Hrvatske, 49/14531 (28. veljače 1988.), 8. Time potvrđuje mišljenje Markite Franulić o promjeni stava izdavača prema racionalnijem korištenju materijala u grafičkoj pripremi što je za posljedicu imalo smanjivanje dimenzija fotografija. Usp.: MARKITA FRANULIĆ, Poletova fotografija 1978.-1981., diplomski rad, Odsjek za povijest umjetnosti, Filozofski fakultet Sveučilišta u Zagrebu, Zagreb, 1995., 22.

6 Na svim informacijama o tehničkim aspektima fotografije koji se navode u tekstu zahvaljujem Hrvoju Matašinu, mag. ing. techn. graph.

7 BRANKO KOSTELNIK, FEĐA VUKIĆ, Uvod: Osamdesete $i$ duh vremena, u: Osamdesete! Slatka dekadencija postmoderne, katalog izložbe, (ur.) Branko Kostelnik, Feđa Vukić, HDLU, DIPK, Zagreb, 10. 4. - 10. 5. 2015., 7-13, 8.

8 INES PRICA, Novi val kao anticipacija krize, Etnološka tribina: godišnjak Hrvatskog etnološkog društva, 13 (1990.), 23-31, 23.

9 DARKO GLAVAN, Na koncertu: lekcije iz sociologije, u: Drugom stranom: almanah novog talasa SFRJ, (ur.) Milena Petrović, Velimir Ćurgus Kazimir, Istraživačko-izdavački centar sso Srbije, Beograd, 1983., 14-20, 19.

10 INES PRICA (bilj. 8), 23-31, 25. Kod pojave punka i novog vala na prostoru Jugoslavije time postaje nužno uzeti u obzir da je riječ o asimiliranju rock-kulture u cjelini koja je pokazala afinitet prema ikonografiji popularne kulture i multimediji, a ne samo prema glazbeno-tekstualnom izrazu.

11 VLADIMIR GUDAC (bilj. 1), 2-104, 10.

12 VLADIMIR ANĐELKOVIĆ, Jugoslavenske potkulture u sedamdesetim, u: Drugom stranom: almanah novog talasa SFRJ, (ur.) Milena Petrović, Velimir Ćurgus Kazimir, Istraživačko-izdavački centar sso Srbije, Beograd, 1983., 117-124, 122.

13 MILANKA ŠAPONJA, Odilustratora do izveštavača: novinska fotografija u Jugoslaviji danas, Foto-kino revija: jugoslovenski časopis za fotografiju i amaterski film, 2 (1982.), 6-7, 6.

14 MARKITA FRANULIĆ (bilj. 3), 40-53, 47.

15 SLAVKO TIMOTIJEVIĆ (bilj. 1, 1983.), 52-62, 55.

16 Spomenute informacije o karakteristikama i obilježjima fotografije u Poletu preuzeti su iz: MARKITA FRANULIĆ (bilj. 3), 40-53. Istovremeno je korištenje ovih tehničkih pomagala omogućilo oživljavanje reporterske fotografije. Leica-format filma zbog tehničkih je karakteristika visoke osjetljivosti i praktičnog oblika u kasetama omogućio fotografiranje više snimaka (najčešće 24 ili 36) bez upotrebe stativa i bljeskalice koji se počinje koristiti radi estetskog dojma. Slučaj je to is 
korištenjem širokokutnih objektiva jer su zbog duge ekspozicije i širokog kuta gledanja bili praktičniji za upotrebu u uvjetima slabijeg osvjetljenja i fotografiranja iz ruke jer je u širem kutu gledanja trešnja što se događa prilikom snimanja iz ruke manje zamjetljiva.

17 DAVOR MATIČEVIĆ, Hrvatska fotografija od tisuću devetsto pedesete do danas, $\mathrm{u}$ : Hrvatska fotografija od tisuću devetsto pedesete do danas, katalog izložbe, (ur.) Marija Gattin, Davor Matičević, Tihomir Milovac, Galerija suvremene umjetnosti, Galerija primitivne umjetnosti, Starogradska vijećnica, Studio Muzeja suvremene umjetnosti, 10.1. - 7. 2. 1993., Muzej suvremene umjetnosti (Galerije grada Zagreba), Zagreb, 1997., 9-18.

18 DENIS KULJIš, Fotografija četvrte generacije, Vjesnik Socijalističkog saveza radnog naroda Hrvatske, 44/12721 (30. siječnja 1983.), 8.

19 Ibid.

20 Ibid.

21 Podaci na osnovi uvida u brojeve spomenutih tiskovina.

22 Kada je riječ o Vesovićevu fotografskog radu, film je neizostavan segment. Od tehničkih i stilskih aspekata u kojima su vidljivi karakteristični filmski postupci, istraživanja filmskog medija $\mathrm{u}$ fotografskom gdje gotovo stvara inverziju tehničkog i povijesnog procesa do reminiscencija na poznate filmove u ciklusima. Uz doticanje filmskog medija $\mathrm{u}$ fotografskom, Vesović je radio i kao fotograf na filmovima: Štefica Cvek u raljama života (r. Rajko Grlić, 1984.), San o ruži (r. Zoran Tadić, 1986.), Obećana zemlja (r. Veljko Bulajić, 1986.) i Manifesto (r. Dušan Makavejev, 1988.) za koji je nagraden za specijalne fotografske efekte.

23 MARINA viCULIN, Detalj MO, u: Ivan Posavec: fotografije '71-'02, katalog izložbe, Galerija Klovićevi dvori, Zagreb, 7 11. - 8. 12. 2002., 12-14, 13.

24 DAVOR MATIČEVIĆ (bilj. 3, 1988.a), bez pag. „Meko okidanje“ postalo je i temeljnim konceptom izložbenog sustava kada je riječ o ovoj dvojici fotografa. Davor Matičević tako je prve samostalne izložbe Posavca 1985. godine i Vesovića 1988. godine koncipirao kao nastavak, a taj koncept slijede i izložbe koje je priredila Marina Viculin u Galeriji Klovićevi dvori: 2002. godine Posavčevu te 2003. Vesovićevu. Abrevijaciju „MO “ $u$ potpisu objavljenih fotografija u tisku dodaju i Jasmin Krpan, Goran Trbuljak, Tajana Posavec te Dragan Pešić. Nekoliko fotografija objavljenih u Studentskom listu i u tjedniku Danas potpisano je isključivo kao djelo „MO“.

25 Prema: DAVOR MATIČEVIĆ (bilj. 3, 1988.a), bez pag.

26 DAVOR MATIČEVIĆ (bilj. 3, 1988.a), bez pag.

27 MIRJANA ŠIGIR (bilj. 5, 1988.), 8.

28 MARKITA FRANULIĆ (bilj. 3), 40-53, 43.

29 Ibid., 40-53, 42. Usp.: -, Desetorica s Akademije za kazalište, film i televiziju, Spot: časopis za fotografiju, 8 (1976.), 7-19.

30 MARKITA FRANULIĆ (bilj. 3), 40-53, 42.

31 DAVOR MATIČEVIĆ (bilj. 3, 1988.a), bez pag.

32 MARKITA FRANULIĆ (bilj. 3), 40-53, 42.

33 Prema: MARKITA FRANULIĆ, Ja sam svjetlopis, ljudopis, vremepis, Studentski list: Organ Narodne studentske omladine Zagrebačkog sveučilišta, 8 (971) (1988.), 34-35, 34.

34 Primjerice Damir Fabijanić navodi: „Moj stav: nema Poletove fotografije! Bilo je samo Poletovih fotografa, odličnih, srednjih i lošijih." Usp.: DAMIR FABIJANIĆ, Osamdeset fotografija osamdesetih, u: Osamdesete! Slatka dekadencija postmoderne, katalog izložbe, (ur.) Branko Kostelnik, Feđa Vukić, HDLU, DIPK, Zagreb, 10. 4. - 10. 5. 2015., 123-164, 127.

35 VLADIMIR GUDAC, Hladna izražajnost Poletove fotografije, u: Nova fotografija 3, katalog izložbe, (ur.) Dimitrije Bašičević, CEFFT, Galerije grada Zagreba, Zagreb, prosinac
1979. - siječanj 1980., Salon Muzeja suvremene umjetnosti, Beograd, ožujak - travanj 1980., Razstavni salon Rotovž Maribor, srpanj 1980., bez pag.

36 SLAVKo TIMOTIJEVIĆ (bilj. 1, 1983.), 52-62, 55.

37 Podaci na osnovi istraživanja Vesovićevih fotografija objavljenih u časopisima Polet, Studentski list, Start i Danas.

38 ADRIAN BAILEY, ADRIAN HOLLOWAY, Sve o fotografiji u boji, Izdavačko poduzeće „Mladost“, Zagreb, 1979., 116.

39 DAVOR MATIČEVIĆ (bilj. 3, 1988.a), bez pag. Snimanje sekvenci prepoznatljiv je Vesovićev fotografski postupak, a prisutan je u i kasnijim fotografskim ciklusima, od 1990. godine do danas. Tim se postupkom postiže da niz statičnih slika daje dojam narativnosti i uvođenja vremenske komponente. Kod snimanja sekvenci Vesović često koristi srednji plan. Uz mogućnost bilježenja odnosa čovjeka i okoline, koju ovaj plan pruža, kada se kao horizontalan položaj kamere koristi u sekvenci, postaje i komentarom autora. Više o srednjem planu i autorskom kadru u: ANTE PETERLIĆ, Osnove teorije filma, Hrvatska sveučilišna naklada, Zagreb, 2001., 78-80, 61-64. Česta Vesovićeva praksa u snimanju portreta rezanje je glave fotografirane osobe $u$ krupnom planu ili rezanje dijelova tijela u srednjem planu. Davor Matičević to naziva „snimanjem u maniri amerikan-šnite“ koje se, prema njegovu mišljenju, javlja pod utjecajem filmskog i televizijskog kadra. Usp.: DAVOR MATIČEVIĆ (bilj. 3, 1988.a), bez pag. U tim je postupcima također prepoznatljiv utjecaj studija filmskog snimanja.

40 Krupni plan individualizira lice snimane osobe i prikazuje intenzitet unutrašnjeg života zbog čega ovaj plan ima izrazite psihološke vrijednosti te preuzima ulogu autorova komentara. Više o krupnom planu u: ANTE PETERLIĆ (bilj. 39), 70-74. Takoder, vrijednost komentara poprima i upotreba širokokutnih objektiva u portretnoj fotografiji jer se u pravilu ne koriste u tom žanru.

41 VLADIMIR GUDAC (bilj. 1), 2-104, 3.

42 Prema: MARKITA FRANULIĆ (bilj. 3), 40-53, 45.

43 DAVOR MATIČEVIĆ (bilj. 3, 1988.a), bez pag.

44 Više o ironiji u fotografiji u: BILJANA SCOTT, Picturing irony: The subversive power of photography, Visual Communication, 3 (2004.), 32-59.

45 SLAVKO TIMOTIJEVIĆ (bilj. 1, 1983.), 56-62, 54.

46 KenNeth Clark, The Nude: A Study in Ideal Form, Princeton University Press, Princeton, 1956.

47 Ibid.

48 NORBERT ELIAS, O procesu civilizacije: sociogenetska $i$ psihogenetska istraživanja: 1-2, Izdanja Antibarbarus, Zagreb, 1996., 507.

49 Ibid., 506-507.

50 KENNETH CLARK (bilj. 46).

51 FRANCES BORZELLO, The Naked Nude, Thames \& Hudson Inc., New York, 2012.

52 JOVAN ČEKIĆ, Telo $u$ umetnosti, u: Neki primjeri akta kao teme u hrvatskoj umjetnosti od Bukovca do Gotovca i dalje, katalog izložbe, (ur.) Davor Matičević, Galerija suvremene umjetnosti i CEFFT, Galerije grada Zagreba, Zagreb, 12. 5 - 12. 6. 1988., bez pag.

53 DAVOR MATIČEVIĆ (bilj. 3, 1988.b), bez pag.

54 Zvonko Maković u tekstu o ciklusu Rosebud ističe Vesovića kao „možda našeg jedinog fotografa koji je zaokupljen temom akta“. Usp.: zvONKO MAKOvić (bilj. 3), 54-55, 55.

55 LEILA MEHULIĆ (bilj. 3), 5.

56 Prema: ŽELJKO KRUŠELJ, Igraonica za odrasle: Polet 1976.1990., Adamić, Novi list, Rijeka, 2015., 241.

57 Prema: Ibid., 242.

58 DAVOR MATIČEVIĆ (bilj. 3, 1985.), bez pag.

59 ŽELJKO KRUŠELJ (bilj. 56), 237-238. 


\section{REFERENCES}

60 DAVOR MATIČEVIĆ (bilj. 3, 1988.a), bez pag.

61 Puni naziv spomenute umjetničke akcije Tomislava Gotovca glasi: Ležanje gol na asfaltu i ljubljenje asfalta (Zagreb volim te!), Hommage Howardu Hawksu i njegovu filmu Hatari, 1961.

62 Uz Vesovića, umjetničku akciju Tomislava Gotovca fotografirali su Ivan Posavec i Boris Turković.

63 ŽELIMIR KOŠČEVIĆ, U fokusu: ogledi o hrvatskoj fotografiji, Školska knjiga, Zagreb, 2006., 129. Tekst objavljen uz fotografije glasi: „11. mjesec (studeni) u 12 sati u petak 13. V. 1981. Radni naslov akcije: ležanje gol na asfaltu, ljubljenje asfalta; lokacija: početak Ilice i Trg Republike; tema akcije: razmatranje problema iz estetike igranog filma - hommage Howardu Hawksu i njegovu filmu Hatari! Gola ljudska figura u urbanom prostoru."

64 Naziv ciklusa posveta je snimljenih fotografija Aljošinu ocu Vladimiru Roksandiću.

65 DAVOR MATIČEVIĆ (bilj. 3, 1988.b), bez pag

66 DAVOR MATIČEVIĆ (bilj. 3, 1985.), bez pag.

67 Goran Trbuljak, navodi Davor Matičević, predlaže izlaganje spomenute „foto-sekvence s pomakom u rasporedu da bi se postiglo i čitanje u drugom smjeru“. U katalog izložbe uvrštena je i skica postava Gorana Trbuljaka. Usp.: DAVOR MATIČEviĆ (bilj. 3, 1985.), bez pag. Na spomenutoj izložbi bilo je predstavljeno deset fotografija. U katalozima izložbi koje su priredile LEILA MEHULIĆ (bilj. 3), 20-23, i BOJANA PEJIĆ (bilj. 3), 220, reproducirano je ili u kataloškom opisu evidentirano dvanaest fotografija u vlasništvu autora. $117-124$. York, 2012. Zagreb, 1996.
14. salon mladih, exhibition catalogue, (ed.) Slavomir Drinković, HDLU, Zagreb, 1982.

VLADIMIR ANĐELKOVIĆ, Jugoslavenske potkulture u sedamdesetim, in: Drugom stranom: almanah novog talasa SfRJ, (eds.) Milena Petrović, Velimir Ćurgus Kazimir, Istraživačko-izdavački centar sso Srbije, Beograd, 1983,

ADRIAN BAILEY, ADRIAN HOLLOWAY, Sve o fotografiji u boji, Izdavačko poduzeće „Mladost“, Zagreb, 1979.

FRANCES BORZELLO, The Naked Nude, Thames \& Hudson Inc., New

KENNETH CLARK, The Nude: A Study in Ideal Form, Princeton University Press, Princeton, 1956.

JOVAN ČEKIĆ, Telo u umetnosti, in: Neki primjeri akta kao teme u hrvatskoj umjetnosti od Bukovca do Gotovca i dalje, exhibition catalogue, (ed.) Davor Matičević, Galerija suvremene umjetnosti, CEFFT, 1988, [s. p.].

-, Desetorica s Akademije za kazalište, film i televiziju, Spot: časopis za fotografiju, 8 (1976), 7-19.

NORBERT ELIAS, 0 procesu civilizacije: sociogenetska i psihogenetska istraživanja: 1-2, Izdanja Antibarbarus,

DAMIR FABIJANIĆ, Osamdeset fotografija osamdesetih, in: Osamdesete! Slatka dekadencija postmoderne, exhibition catalogue, (eds.) Branko Kostelnik, Feđa Vukić, HDLU, DIPK, Zagreb, 2015, 123-164.

MARKITA FRANULIĆ, Ja sam svjetlopis, ljudopis, vremepis, Studentski list: Organ Narodne studentske omladine Zagrebačkog sveučilišta, 8 (971) (1988), 34-35.

MARKITA FRANULIĆ, Poletova fotografija - deset godina kasnije, Život umjetnosti: časopis za pitanja likovne kulture, 45-46 (1989), 40-53.

MARKITA FRANULIĆ, Poletova fotografija 1978.-1981., MA Thesis, Odsjek za povijest umjetnosti, Filozofski fakultet Sveučilišta u Zagrebu, Zagreb, 1995.

DARKO GLAVAN, Na koncertu: lekcije iz sociologije, in: Drugom stranom: almanah novog talasa SFRJ, (eds.) Milena Petrović, Velimir Ćurgus Kazimir, Istraživačko-izdavački centar sso Srbije, Beograd, 1983, 14-20.

VLADIMIR GUDAC, Hladna izražajnost Poletove fotografije, in: Nova fotografija 3, exhibition catalogue, (ed.) Dimitrije Bašičević, CEFFT, Galerije grada Zagreba, Zagreb, 1979, [s. p.].

VLADIMIR GUDAC, Nova novinska fotografija, Pitanja: društvo, znanost, kultura, 10/12 (1980), 2-104.

BRANKO KOSTELNIK, FEĐA VUKIĆ, Uvod: Osamdesete i duh vremena, in: Osamdesete! Slatka dekadencija postmoderne, exhibition catalogue, (eds.) Branko Kostelnik, Feđa Vukić, HDLU, DIPK, Zagreb, 2015, 7-13.

ŽELIMIR KOŠČEVIĆ, U fokusu: ogledi o hrvatskoj fotografiji, Školska knjiga, Zagreb, 2006.

Krivo srastanje, exhibition catalogue, (ed.) Leila Topić, Muzej suvremene umjetnosti, Zagreb, 2015.

ŽELJKO KRUŠELJ, Igraonica za odrasle: Polet 1976.-1990., Adamić, Novi list, Rijeka, 2015

ZRINKA KUIĆ, Poletova fotografija, MA Thesis, Odsjek za povijesti umjetnosti, Filozofski fakultet Sveučilišta u Zagrebu, Zağreb, 2005.

DENIS KULJIŠ, Fotografija četvrte generacije, Vjesnik Socijalističkog saveza radnog naroda Hrvatske, 44/12721 (30 January 1983), 8.

zVONKO MAKOVIĆ, U ime ruže, Život umjetnosti: časopis za pitanja likovne kulture, 45-46 (1989), 54-55.

DAVOR MATIČEVIĆ, Rosebud (pupoljak) Mio Vesović, exhibition catalogue, CEFFT, Galerije grada Zagreba, Zagreb, 1985. 
DAVOR MATIČEVIĆ, Neki primjeri akta kao teme u hrvatskoj umjetnosti od Bukovca do Gotovca i dalje, in: Neki primjeri akta kao teme u hrvatskoj umjetnosti od Bukovca do Gotovca i dalje, exhibition catalogue, (ed.) Davor Matičević, Galerija suvremene umjetnosti, CEFFT, Zagreb, 1988, [s. p.]. DAVOR MATIČEVIĆ, Vesović, exhibition catalogue, CEFFT, Galerije grada Zagreba, Zagreb, 1988.

DAVOR MATIČEVIĆ, Hrvatska fotografija od tisuću devetsto pedesete do danas, in: Hrvatska fotografija od tisuću devetsto pedesete do danas, exhibition catalogue, (eds.) Marija Gattin, Davor Matičević, Tihomir Milovac, Muzej suvremene umjetnosti, Zagreb, 1997, 9-18.

LEILA MEHULIĆ, Ime ruže, in: Mio Vesović Rosebud II, exhibition catalogue, Radnička galerija, Zagreb, 2015, 4-27.

Nova fotografija 3, exhibition catalogue, (ed.) Dimitrije Bašičević, CEFFT, Galerije grada Zagreba, Zagreb, 1979.

Osamdesete! Slatka dekadencija postmoderne, exhibition catalogue, (eds.) Feđa Vukić, Branko Kostelnik, HDLU, DIPK, Zagreb, 2015.

BOJANA PEJIĆ, Negotiating Private Spaces, in: Gender check: femininity and masculinity in the art of Eastern Europe, exhibition catalogue, (ed.) Bojana Pejić, Verlag der Buchhandlung Walther König', Köln, 143-227.

ANTE PETERLIĆ, Osnove teorije filma, Hrvatska sveučilišna naklada, Zagreb, 2001.

INES PRICA, Novi val kao anticipacija krize, Etnološka tribina: godišnjak Hrvatskog etnološkog društva, 13 (1990), 23-31.

BILJANA SCOTT, Picturing irony: The subversive power of photography, Visual Communication, 3 (2004), 32-59.

MILANKA ŠAPONJA, Od ilustratora do izveštavača: novinska fotografija u Jugoslaviji danas, Foto-kino revija: jugoslovenski časopis za fotografiju i amaterski film, 2 (1982), 6-7.

MIRJANA ŠIGIR, Okviri darovitosti, Vjesnik Socijalističkog saveza radnog naroda Hrvatske, 49/14531 (28 February 1988), 8.

SLAVKO TIMOTIJEVIĆ, Novotalasna fotografija u rock-ključu, in: Drugom stranom: almanah novog talasa SFRJ, (eds.) Milena Petrović, Velimir Ćurgus Kazimir, Istraživačko-izdavački centar sso Srbije, Beograd, 1983, 52-62.

SLAVKO TIMOTIJEVIĆ, Fedor Vučemilović: Fotografija i video, exhibition catalogue, Srećna galerija, SKC, Beograd, 1984, [s. p.].

SLAVKO TIMOTIJEVIĆ, Mio Vesović/MO - Meko okidanje, exhibition catalogue, Srećna galerija, Skc, Beograd, 1985.

MARINA VICULIN, Detalj MO, in: Ivan Posavec: fotografije '71-'02, exhibition catalogue, Galerija Klovićevi dvori, Zagreb, 2002, 12-14.

MARINA VICULIN, Mio Vesović: fotografije '76 - '03, exhibition catalogue, Galerija Klovićevi dvori, Zagreb, 2003. 


\section{Newspaper Photography by Mio Vesović (1976-1990)}

A new approach to newspaper photography which emerged in youth magazines Polet and Studentski list in the late 1970 s marked the youth press production of the following decade. The renewed interest for reportage and social photography enabled the establishment of a generation of young photographers: D. Dučak, S. Knaflec, I. Posavec, D. Kalenić, F. Vučemilović, Š. Strikoman, J. Krpan, G. Pavelić, A. Zelmanović and Milisav Mio Vesović (Gornja Dobrinja, 1953). The paper analyses Vesović's activity as newspaper photographer for magazines Polet (1976-1990), Studentski list (1946-1998), Danas (1982-1992) and Start (1962-1991). The author considers Vesović's photographs published between 1976 and 1990 in the context of thematic, technological, stylistic, sociological and cultural conditions in order to cover all aspects of Vesović's work of the period and to assess the influence of the new aesthetics of photography on the artist's oeuvre. Vesović's magazine contributions reveal his affinity towards social themes - portraits, nudes and reportage photography, through which he created a distinct visual language pertinent to these genres, applied with the intent of documenting the time and social context which marked his professional activity. Specific features of Vesović's visual expression are author's comments which accompany the documented reality, which distinguishes him as a photographer who sees photography as a discourse which permits him to convey a personal attitude, humour or irony. Due to his specific visual language and his extensive activity as newspaper photographer, Vesović's career path developed from amateur photography in the late 1970s to professional photography in the early 1990s, with his contributions produced over the last three decades becoming a key segment of the history of photography in Croatia.

MARIJA PERKEC (1991.) diplomirala je povijest umjetnosti i komparativnu književnost 2016. godine na Filozofskom fakultetu Sveučilišta u Zagrebu. Iste godine počinje raditi u Grafičkoj zbirci Nacionalne i sveučilišne knjižnice u Zagrebu u okviru programa stručnog osposobljavanja za zvanje kustosa.
MARIJA PERKEC (1991) received her MA in Art History and Comparative Literature from the Faculty of Humanities and Social Sciences, University of Zagreb in 2016. She is currently attending the curatorial traineeship programme at the Print Collection of the National and University Library in Zagreb. 